\title{
Bats and zoonotic viruses: can we confidently link bats with emerging deadly viruses?
}

\author{
Ricardo Moratelli ${ }^{+}$, Charles H Calisher ${ }^{2}$
}

\begin{abstract}
${ }^{1}$ Fiocruz Mata Atlântica, Rio de Janeiro, RJ, Brasil 2Arthropod-borne and Infectious Diseases Laboratory, Department of Microbiology, Immunology and Pathology, College of Veterinary Medicine and Biomedical Sciences, Colorado State University, Fort Collins, CO, USA
\end{abstract}

An increasingly asked question is 'can we confidently link bats with emerging viruses?'. No, or not yet, is the qualified answer based on the evidence available. Although more than 200 viruses - some of them deadly zoonotic viruses - have been isolated from or otherwise detected in bats, the supposed connections between bats, bat viruses and human diseases have been raised more on speculation than on evidence supporting their direct or indirect roles in the epidemiology of diseases (except for rabies). However, we are convinced that the evidence points in that direction and that at some point it will be proved that bats are competent hosts for at least a few zoonotic viruses. In this review, we cover aspects of bat biology, ecology and evolution that might be relevant in medical investigations and we provide a historical synthesis of some disease outbreaks causally linked to bats. We provide evolutionary-based hypotheses to tentatively explain the viral transmission route through mammalian intermediate hosts and to explain the geographic concentration of most outbreaks, but both are no more than speculations that still require formal assessment.

Key words: bat-borne viruses - biosafety - Chiroptera - bat immunology - emerging infectious diseases - zoonosis

Taxonomically, bats are grouped in the order Chiroptera (Gr. cheir, hand; pteron, wing) and, as the name suggests, they have morphological and physiological adaptations for powered flight. These characteristics and the ecosystem services they provide set them apart from all other mammals. Other aspects of their natural history, ecology, biology and evolution also distinguish them from other mammals, but none has been more emphasised recently than their potential link with human diseases, particularly those caused by zoonotic viruses (Wibbelt et al. 2010, Kupferschmidt 2013, Luis et al. 2013, Plowright et al. 2015).

Although many bat viruses have been associated with human, livestock and wild animal diseases, the sudden appearance of newly recognised viruses causing dreadful diseases has been surprising, sometimes shocking to the scientific and medical communities. Humans have responded to these diseases in rapid and often unprepared and disorganised ways. In part, this has occurred because bat biologists have been in denial regarding their favourite mammals due to the fear of further damage to the illogical and false reputation of bats as vampires and as

doi: 10.1590/0074-02760150048

Financial support: PAPES, FIOCRUZ, CNPq (407623/2012-4),

CNPq/CsF (202612/2012), FAPERJ (E-26/111.288/2014),

Smithsonian Institution (USA)

RM current address: Division of Mammals, National Museum of

Natural History, Smithsonian Institution, Washington DC, USA

+ Corresponding author: rmoratelli@fiocruz.br

Received 3 February 2015

Accepted 9 February 2015 carriers of rabies virus. This has been a disservice to both our understanding of the biology of bats and to the various medical and research communities and their patrons. False images of bats engendered by entertaining, but preposterous motion pictures, alarmist stories in the popular press and ancient superstitions have been embedded in the minds of the public and have impeded education and acceptance of these remarkable, useful and widely diverse animals. Thus, until relatively recently, studies of the relationships of bats and viruses have lagged far behind studies of viruses in humans, livestock, birds, other wild vertebrates and arthropods (Calisher et al. 2006).

With human encroachment on natural areas intensifying, particularly in those with high biological richness (Myers et al. 2000, Ceballos \& Ehrlich 2006) and bats recognised as important reservoirs of zoonotic viruses (Luis et al. 2013), considerable concern and interest have been expended on them. In addition, bats of some species adapt well to disturbed habitats (Jones et al. 2009), so that these vertebrates have quickly become a focus of epidemiologic studies. However, most epidemiologists know bats only from outdated information or know very little or nothing about their biology, ecology and evolution. A similar situation occurs regarding bat biologists, many of whom know little or nothing about diseases ostensibly associated with bats. In an attempt to fill the gaps in knowledge about bats in general, bats as virus hosts and bat diseases, we review many aspects of bat biology, ecology and evolution, which we expect will enlighten medical investigations. In addition, we provide a historical synthesis of disease outbreaks causally linked to bats and which have caused isolated deaths or severe outbreaks of diseases. By linking these aspects, we then attempt to fit together some pieces of this puzzle. We anticipate that this review will stimulate collaborations between bat biologists and medical researchers in field and laboratory investigations concerning both basic and applied research. 
TABLE I

Synthesis of the distribution and diet of bats by family

\begin{tabular}{|c|c|c|c|}
\hline Family (number of species) ${ }^{a}$ & Common names ${ }^{b}$ & Distribution & Feeding items \\
\hline Cistugidae (2) & Winged-gland bats & Southern Africa & Insects \\
\hline Craseonycteridae (1) & Bumblebee bats & Thailand, Burma & Insects, spiders \\
\hline Emballonuridae (54) & Sheath-tailed bats & Pantropical & Insects, occasionally fruits \\
\hline Furipteridae (2) & Smoky bats & Neotropics & Insects \\
\hline Hipposideridae (9) & Old World leaf-nosed bats & $\begin{array}{l}\text { Old World tropics } \\
\text { and subtropics }\end{array}$ & Insects \\
\hline Megadermatidae (5) & False vampire bats & Old World tropics & Arthropods, small vertebrates \\
\hline Miniopteridae (29) & Bent-winged bats & $\begin{array}{l}\text { Old World tropics } \\
\text { and subtropics }\end{array}$ & Insects \\
\hline Molossidae (113) & Free-tailed bats & Pantropical & Insects \\
\hline Mormoopidae (10) & Moustached bats & Neotropics & Insects \\
\hline Mystacinidae (2) & New Zealand short-tailed bats & New Zealand & $\begin{array}{l}\text { Insects and other arthropods; } \\
\text { also feeding on nectar and fruits }\end{array}$ \\
\hline Myzopodidae (2) & Old World disk-winged bats & Madagascar & Insects \\
\hline Natalidae (12) & Funnel-eared bats & Neotropics & Insects \\
\hline Noctilionidae (2) & Bulldog bats & Neotropics & Insects; 1 specie feeds on fishes \\
\hline Nycteridae (16) & Slit-faced bats & Old World tropics & $\begin{array}{c}\text { Insects, spiders, scorpions; } \\
1 \text { specie feeds on small vertebrates }\end{array}$ \\
\hline Phyllostomidae (204) & New World leaf-nosed bats & Neotropics & Animals and plants \\
\hline Pteropodidae (198) & Old World fruit bats & $\begin{array}{l}\text { Old World tropics } \\
\text { and subtropics }\end{array}$ & Fruits, nectar, pollen \\
\hline Rhinolophidae (97) & Horseshoe bats & $\begin{array}{l}\text { Old World tropics } \\
\text { and subtropics }\end{array}$ & Insects \\
\hline Rhinopomatidae (6) & Mouse-tailed bats & Old World tropics & Insects \\
\hline Thyropteridae (5) & New World disk-winged bats & Neotropics & Insects \\
\hline Vespertilionidae (455) & Vesper bats & Cosmopolitan & $\begin{array}{l}\text { Most species feed exclusively on insects, } \\
\text { but a few also feed on other arthropods } \\
\text { (like scorpions), fishes and small birds }\end{array}$ \\
\hline
\end{tabular}

$a, b$ : scientific and vernacular family group names and numbers of species follow Fenton and Simmons (2015).

\section{Biology, diversity and evolution of bats}

Diversity, distribution and biology - Bats vary widely in size and form. Their body masses range from $2 \mathrm{~g}$ in the bumblebee bat [Craseonycteris thonglongyai (Craseonycteridae), the second smallest mammal known] to 1 $\mathrm{kg}$ in some flying-foxes [Pteropus spp (Pteropodidae)], whose wingspans can reach $2 \mathrm{~m}$ (Wilson 1997). Among mammals, bats are second only to rodents in species richness, with more than 1,300 species recognised currently (Fenton \& Simmons 2015). This total comprises almost one fifth of the world's mammal species, with more than 175 genera (Simmons 2005, Wilson \& Reeder 2005) arranged in 20 families.

Bats are distributed widely in the world, occurring on all continents, except Antarctica. They are the second most widespread order of mammals, surpassed only by Primates due to the wide distribution of humans. Due to their ability to fly, they have colonised many oceanic islands and on some they are the only native mammals (Koopman 1994). Among the families recognised currently (Fenton \& Simmons 2015), Emballonuridae, Mo- lossidae and Vespertilionidae occur in both the New and Old World, Cistugidae, Craseonycteridae, Hipposideridae, Megadermatidae, Miniopteridae, Mystacinidae, Myzopodidae, Nycteridae, Pteropodidae, Rhinolophidae and Rhinopomatidae occur only in the Old World, and Furipteridae, Mormoopidae, Natalidae, Noctilionidae, Phyllostomidae and Thyropteridae occur only in the New World. Table I provides information on distribution and diet of bats by family. The evolution of flight - the most peculiar characteristic of bats and one of the most important for their wide distribution - may have had effects on some aspects of the evolution of the immune system and the metabolism of bats, allowing them to host so many viruses (O'Shea et al. 2014, Brook \& Dobson 2015).

Bats are nocturnal mammals (Rydell \& Speakman 1995), with most of them spending the day in roosts and foraging from dusk to dawn. In general, they have one or two peaks of activity throughout the night (Fenton 1983). Tropical bats are active year-round and those that live in temperate zones either migrate or hibernate to avoid unfavourable environmental conditions (Fenton 1983, Wilson 1997). 


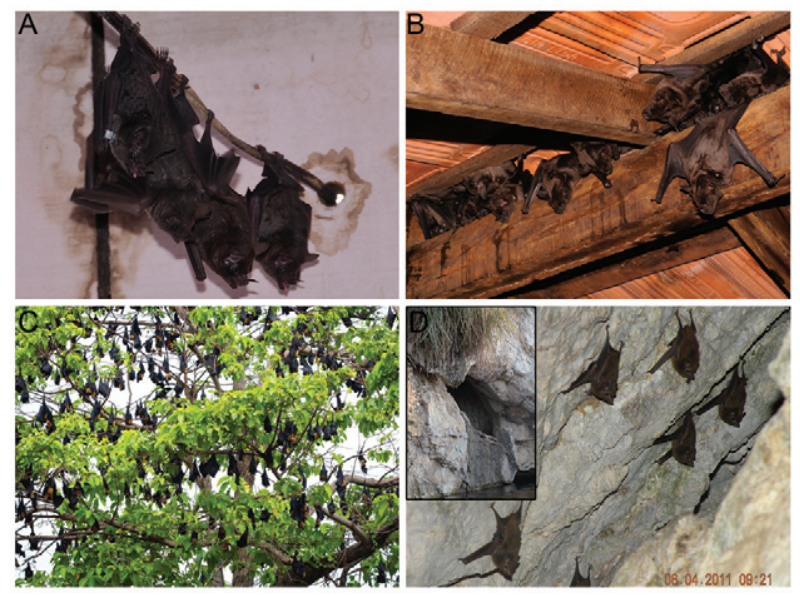

Fig. 1A: Seba's short-tailed bats [Carollia perspicillata (Phyllostomidae)]; B: greater spear-nosed bats [Phyllostomus hastatus (Phyllostomidae)] using human-made constructions as day roosts; C: flyingfoxes (Pteropidae) hanging on trees during the day; D: lesser dog-like bats [Peropteryx macrotis (Emballonuridae)] roosting in the crevice of a rock in the edge of a river (the inset shows the entrance to the crevice). A and B are courtesy of A Pol (Federal Rural University of Rio de Janeiro, Brazil), C was acquired from Shutterstock Inc and D is courtesy of E Rubião (self-employed contractor). Photographers are the copyright holders of the images.

Bats exploit a great variety of roosts. They can use hollows (caves, mines, tree trunks, buildings etc.), crevices and foliage as day roosts (Fig. 1) and many frugivorous and insectivorous bats are known to use night roosts for eating and grooming. Partially eaten fruits and insects and droppings can be found on the ground of their night roosts (Fenton 1983) and they are good indicators of the items included in their diet. Fruits partially eaten by bats have been used to link bats with emerging zoonotic viruses (Chua et al. 2002).

Bat reproduction is similar to that of other mammals, but mating and duration of breeding season are strongly influenced by hibernation and migration. In hibernating bats of various species, copulation generally occurs in the fall, either with ovulation and fertilisation occurring immediately, followed by a slow development of the fetus throughout the winter and birth in the spring, or with sperm storage until spring, after which ovulation, fertilisation and foetal development occurs. In migratory bats, mating is generally concentrated in the early spring, after they reach their summer roosts. These bats and several others that do not need to migrate or hibernate, but that live in areas with food availability varying seasonally, reproduce once a year (monoestrus), whereas others facing less marked seasonal variation or having food resources available year-round generally reproduce twice or more a year (polyestrus). The former pattern is characteristic of most insectivorous bats from temperate regions, whereas the latter is common in most frugivorous bats living in tropical regions. Gestation averages about two months and bats of most species produce a single young per litter, but a few produce twins and a very few produce three or four young at a time (Wilson 1997). Halpin et al. (2000) isolated Hendra virus from uterine fluid and foetal tissues of bats and Drexler et al. (2011) found evidence of virus amplification during colony formation and after parturition.

Life span usually decreases with body size for mammals, with larger animals living longer, but bats are exceptions to this rule; longevity in bats was reviewed by Wilkinson and South (2002). Bats can live 3.5 times longer, on average, than non-volant placental mammals with similar body size (Wilkinson \& South 2002) and, considering their size, they live longer than any other mammal (Bouliere 1958, Austad \& Fischer 1991). The maximum age varies greatly from species to species, but while small rodents live in the wild about one-two years, a bat with similar body size can live more than 30 years. A Brandt's bat [Myotis brandtii (Vespertilionidae)] from Siberia was recaptured 41 years after the first capture (Podlutsky et al. 2005), but records of bats older than 30 years are known only for bats of five species in the wild (Wilkinson \& South 2002). Genome and transcriptome analyses have revealed unique sequence changes that appear to contribute to both the small body size and the long lifespan of bats (Seim et al. 2013).

Species richness increases toward the tropics and in most tropical areas bat diversity is higher than that of any other group of mammals. As an example, in a 3-km radius of a rainforest in northern French Guiana, bats of at least 78 species co-exist in the area and the diversity analyses indicate that the fauna is not fully sampled (Simmons \& Voss 1998). In the same area, 64 non-volant mammals have been recorded, including 22 rodents, 12 marsupials, 10 carnivores, nine xenarthrans, six primates and five ungulates (Voss et al. 2001). Bats also are the most abundant mammals in several tropical forests and the wild vertebrates that more often interact with humans, although most people do not realise it.

Bats of some species also form large aggregations and a few of them form the largest aggregations of mammals in the world. Old World fruit bats (Pteropodidae) of various species constitute colonies of hundreds of thousands to millions of bats that aggregate on exposed tree branches (Mickleburgh et al. 1992, Kunz \& Pierson 1994). In Bracken Cave, central Texas, about 20 million Mexican free-tailed bats [Tadarida brasiliensis mexicana (Molossidae)] form the largest warm-blooded nonhuman vertebrate colony in the world.

Although bats are outnumbered by rodents in species richness, they are first among mammals (and probably among vertebrates) in dietary diversity (Fenton \& Simmons 2015) which includes remarkable adaptations to explore an array of different animal and plant food items (Wilson 1973, 1997, Altringham 1996, 2011). This variety of behaviours has been arranged into eight main feeding categories: fruit eaters, flower feeders, aerial insectivores (those that capture insects in flight), foliage gleaners (capture insects on the ground), carnivores (feed on small terrestrial vertebrates, including birds, frogs and mammals), fish eaters, blood feeders and omnivores (Wilson 1973). Phyllostomids - also called New World leaf-nosed bats and restricted to the Neotropics - include representatives classified in quite distinct categories (Fig. 2A-F), with insect foliage gleaners, carnivores, blood feeders, nectar feeders and fruit eaters; the latter mainly grouped into the subfamilies Stenodermatinae, Carolliinae and Rhi- 

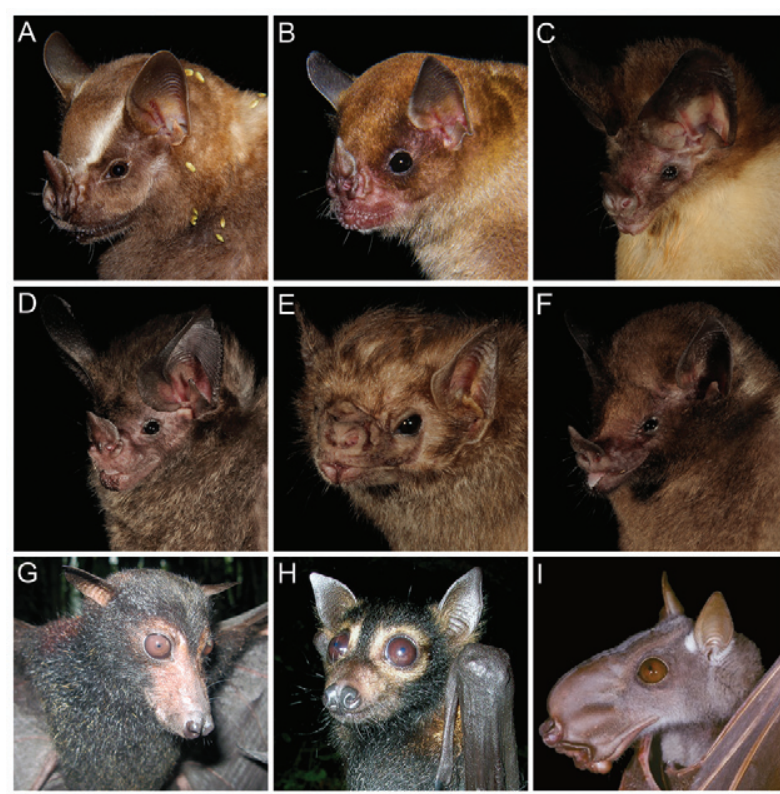

Fig. 2A-F: New World leaf-nosed bats of family Phyllostomidae, including frugivores - the great-eating fruit bat (Artibeus lituratus) (A) with seeds in the fur and the little yellow-shouldered bat (Sturnira lilium) (B), insect eaters - the common big-eared bat (Micronycteris cf. microtis) (C) and the stripe-headed round-eared bat (Tonatia saurophila) (D), a blood feeder - the white-winged vampire bat (Diaemus youngi) (E) and a nectar feeder - the Thomas's nectar bat (Hsunycteris thomasi) (F); G-I: Old World fruit bats of family Pteropodidae, including the black flying-fox (Pteropus alecto) $(\mathrm{G})$, the spectacle flying-fox (Pteropus conspicillatus) $(\mathrm{H})$ and the hammer-headed fruit bat (Hypsignathus monstrosus) (I). A and B are courtesy of RLM Novaes (Oswaldo Cruz Foundation, Brazil), C-F are courtesy of A Pol (Federal Rural University of Rio de Janeiro, Brazil), G and $\mathrm{H}$ are courtesy of A Breed (Animal and Plant Health Agency, Addlestone, Surrey, United Kingdom) and I is courtesy of Jakob Fahr (Max Planck Institute for Ornithology, Germany). Photographers are the copyright holders of the images

nophyllinae. Pteropodids - the fruit bats restricted to the Old World tropics (Old World fruit bats) - also include fruit eaters and nectar feeders (Fig. 2G-I). Except for representatives of these two families, bats are primarily animal feeders, generally insect eaters. Some pteropodid and phyllostomid bats that feed on fruits reject the fibres and other indigestible components. They chew and ingest the pulp and juices and drop the fibrous material and larger seeds that can be found on the ground below their night roosts. They swallow smaller seeds that pass quickly and undamaged through the bat's gastrointestinal tract (ca. $20 \mathrm{~min}$ ). Using a similar strategy to increase feeding efficiency, insect-eaters from various families may cull the insects they prey on, consuming the most nutritional part (the abdomen) and discarding wings, head and appendages (Fenton 1983, Kunz et al. 2011).

Evolutionary history - Chiroptera is a middle Paleocene or early Eocene lineage of placentals (Simmons et al. 2008, O'Leary et al. 2013). This means that bats have evolved apart from other mammalian lineages for more than 50 million years. Although they have a long history of isolation from other mammals, understanding their evolutionary relationships with other groups of mam- mals and even between bats of different families, can provide important clues in investigating physiological aspects that may favour disease spillover events.

Bats comprise a monophyletic lineage that has evolved within the superorder Laurasiatheria (Van Den Bussche \& Hoofer 2004, O'Leary et al. 2013). This superorder also includes the order Lipotyphla [formerly Insectivora, but excluding tenrecs (Tenrecidae) and golden moles (Chrysochloridae)], Pholidota (pangolins or scaly anteaters), Carnivora (carnivores), Perissodactyla (horses, tapirs, rhinoceroses and other odd-toed ungulates) and Artiodactyla [pigs, cattle, deer and other even-toed ungulates; dolphins and whales (O'Leary et al. 2013)].

Since Dobson's (1875) basal division of Chiroptera into the suborders Megachiroptera (also referred to as 'megabats', Old World fruit bats or flying-foxes) and Microchiroptera ('microbats'), these two groups have been widely accepted. In this arrangement, Megachiroptera comprised only Pteropodidae and Microchiroptera included all other families (Koopman 1994). This classification was widely used for more than a century, but it is no longer accepted by bat systematists. Currently, Yinpterochiroptera (Rhinolophoidea + Pteropodidae) and Yangochiroptera (all other families) are the two most basal lineages recognised within the Chiroptera (Springer et al. 2001, Van Den Busshe \& Hoofer 2004). A more in-depth overview of the historical classification of Chiroptera is available in the Supplementary data. Other information about echolocation and ecosystem services provided by bats are available in the Supplementary data as well.

\section{Important disease outbreaks associated with bats}

Following are some examples of viruses of humans and livestock associated with bats and which have been important in many ways, including bringing bats to the attention of the scientific and medical communities. Studies of these diseases, their causative agents, the peculiar biology of bats, the relationships of bat viruses to other viruses, the evolution of these viruses, the causes of disease outbreak initiation (epidemiology), the prevention of diseases and the expanded studies of bats for one reason or another likely will provide more information about the bats themselves and, in the long run, help us protect bat populations from further decline.

Summary of viruses from bats - More than 200 viruses have been isolated from or detected in bats. Represented are bats of both suborders, 11 families and 37 genera (Table II, Supplementary Table II). The viruses are representatives of 27 virus families, which is a remarkable diversity (Calisher 2015). This suggests that viruses detected in bats are unlikely to be there by chance, simply a series of oddities. Indeed, when concerted efforts have been made to search for viruses of specific families, such as coronaviruses (CoVs) and herpesviruses, a large number of these viruses were detected and a substantial proportion of them have been shown to be previously unrecognised viruses or viral subtypes. Because some investigators search only for particular viruses or for viruses of particular families it is certain that many viruses must have been overlooked, so that the lists in the Table II and Supplementary Table II surely underrepresent the actual situation in nature. 
TABLE II

Bat hosts from which the virus or its sequence was first identified ${ }^{a}$

Family

Genus

Virus

Source $^{b, c}$

Adenoviridae

Mastadenovirus

Ryukyu

Bat adenovirus 2

BtAdV 4

Arenaviridae

Arenavirus

Astroviridae

Mamastrovirus

Bornaviridae

Unnamed genus

Bunyaviridae

Orthobunyavirus

Hantavirus

Phlebovirus

Nairovirus
Tacaribe

Many

Bat bornavirus b1

Catu

Guama

Nepuyo

Mojui dos Campos

Kaeng khoi

Araraquara

Hantaan

Huangpi

Longquan

Magboi

Mouyassué

Xuan son

Rift Valley fever

Toscana

Malsoor

Ahun

Gossas
Ryukyu flying-fox

(Pteropus dasymallus yayeyamae)

Common pipistrelle

(Pipistrellus pipistrellus)

Leschenault's rousette

(Rousettus leschenaultii)

Jamaican fruit-eating bat

(Artibeus jamaicensis)

Numerous genera and species

Common pipistrelle

(P. pipistrellus)

Thomas's mastiff bat

(Molossus currentium)

Unidentified bat

Jamaican fruit-eating bat

(A. jamaicensis)

Unidentified bat

Wrinkled-lipped free-tailed bat

(Chaerephon plicatus)

Tailed tailless bat

(Anoura caudifer)

Hairy-legged vampire bat

(Diphylla ecaudata)

Common serotine

(Eptesicus serotinus)

Japanese pipistrelle

(Pipistrellus abramus)

Horseshoe bats

(Rhinolophus affinis,

Rhinolophus sinicus,

Rhinolophus monoceros)

Hairy slit-faced bat

(Nycteris hispida)

Banana pipistrelle

(Neoromicia nanus)

Pomona leaf-nosed bat

(Hipposideros pomona)

Peters's lesser epauletted fruit bat

(Micropteropus pusillus)

Kuhl's pipistrelle

(Pipistrellus kuhlii)

Leschenault's rousette

(R. leschenaultii)

Whiskered myotis

(Myotis mystacinus)

Free-tailed bat

(Tadarida sp.) 


\begin{tabular}{lc}
$\begin{array}{l}\text { Family } \\
\text { Genus }\end{array}$ & Virus \\
\hline Nairovirus & Keterah \\
& Issyk-kul \\
& Yogue \\
& Kasokero \\
Caliciviridae & \\
Sapovirus & Bat sapovirus \\
Circoviridae & \\
Circovirus & \\
Cyclovirus & Cyclovirus T. brasiliensis
\end{tabular}

Coronaviridae

Alphacoronavirus

Human coronavirus

Novel

Betacoronavirus

Dicistroviridae

Filoviridae

Marburgvirus

Ebolavirus

Cuevavirus

Flaviviridae

Flavivirus

Severe acute respiratory syndrome coronavirus (SARS)

Middle East respiratory syndrome coronavirus

Marburg

Zaire

Lloviu

Bukalasa bat
Source $^{b, c}$

Lesser Asiatic yellow house bat (Scotophilus kuhlii)

Common noctule (Nyctalus noctula) Egyptian rousette (Rousettus aegyptiacus) Egyptian rousette (R. aegyptiacus)

Pomona leaf-nosed bat (H. pomona)

Bats of different species Mexican free-tailed bat (Tadarida brasiliensis mexicana)

Sundevall's leaf-nosed bat (Hipposideros caffer)

Small long-fingered bat (Miniopterus pusillus)

New Zealand lesser short-tailed bat (Mystacina tuberculata)

Chinese rufous horseshoe bat (R. sinicus)

Paris dicistrovirus

Carey island

Dakar bat

Entebbe bat

Japanese encephalitis

Jugra
Egyptian tomb bat (Taphozous perforatus)

\section{Common pipistrelle} (P. pipistrellus)

Egyptian rousette (R. aegyptiacus)

Hammer-headed fruit bat (Hypsignathus monstrosus) Franquet's epauletted fruit bat (Epomops franqueti)

Little collared fruit bat (Myonycteris torquata)

Schreibers's long-fingered bat (Miniopterus schreibersii)

Little free-tailed bat (Chaerephon pumilus) Lesser short-nosed fruit bat (Cynopterus brachyotis) Yellow bat (Scotophilus sp.)

Little free-tailed bat (C. pumilus)

Leschenault's rousette (R. leschenaultii)

Lesser short-nosed fruit bat (C. brachyotis) 
Family

Genus

Flavivirus

Hepacivirus

Pegivirus

Pestivirus

Hepadnaviridae

Orthohepadnavirus
Virus

Kyasanur Forest disease

Montana myotis leucoenc.

Phnom-Penh bat

Rio bravo

Saboya

St. Louis encephalitis

Sokuluk

Tamana bat

Usutu

West Nile

Yellow fever

Yokose

Hepatitis C

(clade A)

Hepatitis C

(clade C)

Hepatitis C

(clade D)

Gbv-d

Pegivirus clades

G, H, K

Ra pestivirus 1

Unnamed

Hepatitis B

Hepatitis B

Hepatitis B

Kolente

Hepatitis E virus-like

Parixa

Agua preta
Source $^{b, c}$

Rufous horseshoe bat

(Rhinolophus rouxi)

Little brown myotis

(Myotis lucifugus)

Lesser short-nosed fruit bat

(C. brachyotis)

Mexican free-tailed bat

(T. brasiliensis mexicana)

Gambian slit-faced bat

(Nycteris gambiensis)

Mexican free-tailed bat

(T. brasiliensis mexicana)

Common pipistrelle

(P. pipistrellus)

Common mustached bat

(Pteronotus parnellii)

Common pipistrelle

(P. pipistrellus)

Big brown bat

(Eptesicus fuscus)

Little epauletted fruit bat

(Epomophorus labiatus)

Schreibers's long-fingered bat

(Miniopterus schreibersii fuliginosus)

Striped leaf-nosed bat

(Hipposideros vittatus)

Large-eared giant mastiff bat

(Otomops martiensseni)

Striped leaf-nosed bat

(H. vittatus)

Indian flying-fox

(Pteropus giganteus)

Numerous

Intermediate horseshoe bat (R. affinis)

Schreibers's long-fingered bat (M. schreibersii fuliginosus)

Common tent-making bat

(Uroderma bilobatum)

Noack's leaf-nosed bat

(Hipposideros cf. ruber)

Halcyon horseshoe bat

(Rhinolophus alcyone)

Roundleaf bat

(Hipposideros sp.)

Bechstein's myotis

(Myotis bechsteinii)

Thomas's nectar bat

(Lonchophylla thomasi)

Gray short-tailed bat

(Carollia subrufa) 
Family

Genus

Virus

'A cytomegalovirus'

Many

(Gammaherpesvirinae)

Percavirus, Rhadinovirus, Macavirus

Nodaviridae

Nodavirus

Orthomyxoviridae

Influenza virus A

Papillomaviridae

Omegapapillomavirus

New genus?

Paramyxoviridae

Morbillivirus

Henipavirus

Rubulavirus

Pneumovirus

Unassigned

Parvoviridae

Unnamed PARV4-like

Dependovirus

Bocavirus
Sers nodavirus

Influenza virus A (H17N10)

Influenza virus A

MRPV-1

MSPV-1

Canine distemper-like

Hendra

Nipah

Cedar

Achimota virus 1

Mapuera

Menangle

Mumps

Sosuga

Tioman

Tuhokovirus 3

Unnamed

'A paramyxovirus'

Eh-BtPV-1

BtAAV-YNM

$\mathrm{MmBoV}-1$
Tuhokovirus 1

Tuhokovirus 2
Source $^{b, c}$

Little brown myotis (M. lucifugus)

Bats of different species

Common serotine (E. serotinus)

Little yellow-shouldered bat (Sturnira lilium)

Spix's artibeus (Artibeus planirostris)

Rickett's big-footed bat (Myotis ricketti)

Schreibers's long-fingered bat (M. schreibersii)

Common vampire bat (Desmodus rotundus)

Gray-headed flying-fox (Pteropus poliocephalus)

Variable flying-fox (Pteropus hypomelanus)

Black flying-fox

(Pteropus alecto)

African straw-coloured fruit bat (Eidolon helvum)

Little yellow-shouldered bat (S. lilium)

Black flying-fox (P. alecto)

Epauletted fruit bat (Epomophorus sp.)

Egyptian rousette (R. aegyptiacus)

Variable flying-fox (P. hypomelanus)

Leschenault's rousette (R. leschenaultii)

Leschenault's rousette (R. leschenaultii)

Leschenault's rousette (R. leschenaultii)

African straw-coloured fruit bat (E. helvum)

Leschenault's rousette (R. leschenaultii)

African straw-coloured fruit bat (E. helvum)

Rickett's big-footed bat (M. ricketti)

Mouse-eared myotis (Myotis myotis) 
Family

Genus

Virus

Source $^{b, c}$

Undetermined

Picobirnaviridae

Picobirnavirus

Picornaviridae

Kobuvirus

Unclassified

Polyomaviridae

Undetermined

Poxviridae

Chordopoxvirinae (Molluscipoxvirus)

Chiropoxvirinae

Reoviridae

Orbivirus

Orthoreovirus

Rotavirus

Retroviridae

Betaretrovirus

Spumavirus

Gammaretrovirus

Rhabdoviridae

Lyssavirus
Bat/KE4852/07

Maule

RVA/Bat-tc/MYAS33

Aj-BtPV-1

Unnamed

E. helvum kobuvirus

C16A

Ms picornavirus 1

Ia io picornavirus 1

Ra picornavirus 1

Juruaca

'A polyomavirus'

Molluscum contagiosum-like

Eptesipox

Fomede

Ife

Japanaut

Broome

Nelson bay

Pulau

$\mathrm{Xi}$ river

Endogenous

RaFV-1

Sers gammaretrovirus

Rabies
Jamaican fruit-eating bat

(A. jamaicensis)

Common pipistrelle (P. pipistrellus)

African straw-coloured fruit bat (E. helvum)

Multiple bat sources Schreibers's long-fingered bat (M. schreibersii)

Great evening bat (Ia io)

Intermediate horseshoe bat (R. affinis)

Undetermined bat

Little brown myotis (M. lucifugus)

African straw-coloured fruit bat (E. helvum)

Big brown bat (E.fuscus)

Dwarf slit-faced bat (Nycteris nana)

African straw-coloured fruit bat (E. helvum)

Southern blossom bat (Syconycteris australis crassa)

Little red flying-fox

(Pteropus scapulatus)

Gray-headed flying-fox

(P. poliocephalus)

Variable flying-fox (P. hypomelanus)

Leschenault's rousette

(R. leschenaultii)

African straw-coloured fruit bat (E. helvum)

Whiskered myotis (M. mystacinus)

Stoliczka's Asian trident bat (Aselliscus stoliczkanus)

Bats of different species (from genome databases) Intermediate horseshoe bat (R. affinis)

Common serotine (E. serotinus)

Common vampire bat (D. rotundus) 


\begin{tabular}{|c|c|c|}
\hline $\begin{array}{l}\text { Family } \\
\text { Genus }\end{array}$ & Virus & Source ${ }^{b, c}$ \\
\hline \multirow[t]{12}{*}{ Lyssavirus } & Lagos bat & $\begin{array}{c}\text { African straw-coloured fruit bat } \\
(\text { E. helvum })\end{array}$ \\
\hline & Duvenhage & $\begin{array}{l}\text { Schreibers's long-fingered bat } \\
\text { (M. schreibersii) }\end{array}$ \\
\hline & European bat lyssavirus 1 & $\begin{array}{l}\text { Common serotine } \\
(\text { E. serotinus })\end{array}$ \\
\hline & European bat lyssavirus 2 & $\begin{array}{l}\text { Daubenton's bat } \\
\text { (Myotis daubentonii) }\end{array}$ \\
\hline & Aravan & $\begin{array}{l}\text { Lesser mouse-eared bat } \\
\text { (Myotis blythii) }\end{array}$ \\
\hline & Australian bat lyssavirus & $\begin{array}{l}\text { Black flying-fox } \\
\text { (P. alecto })\end{array}$ \\
\hline & Khujand & $\begin{array}{l}\text { Whiskered myotis } \\
\text { (M. mystacinus) }\end{array}$ \\
\hline & Irkut & $\begin{array}{l}\text { Greater tube-nosed bat } \\
\text { (Murina leucogaster) }\end{array}$ \\
\hline & West Caucasian bat & $\begin{array}{l}\text { Schreibers's long-fingered bat } \\
\text { (M. schreibersii) }\end{array}$ \\
\hline & Bokeloh virus & $\begin{array}{l}\text { Natterer's myotis } \\
\text { (Myotis nattereri) }\end{array}$ \\
\hline & Shimoni bat & $\begin{array}{l}\text { Commerson's leaf-nosed bat } \\
\text { (Hipposideros commersoni) }\end{array}$ \\
\hline & Lleida bat lyssavirus & $\begin{array}{l}\text { Schreibers's long-fingered bat } \\
\text { (M. schreibersii) }\end{array}$ \\
\hline Vesiculovirus & American bat vesiculovirus & $\begin{array}{c}\text { Big brown bat } \\
(\text { E. fuscus })\end{array}$ \\
\hline \multirow[t]{4}{*}{ Unassigned } & Fikirini & $\begin{array}{l}\text { Striped leaf-nosed bat } \\
\text { (H. vittatus })\end{array}$ \\
\hline & Kern canyon & $\begin{array}{c}\text { Yuma myotis } \\
\text { (Myotis yumanensis) }\end{array}$ \\
\hline & Mount Elgon bat & $\begin{array}{l}\text { Eloquent horseshoe bat } \\
\text { (Rhinolophus eloquens) }\end{array}$ \\
\hline & Oita 296 & $\begin{array}{l}\text { Little Japanese horseshoe bat } \\
\text { (Rhinolophus cornutus) }\end{array}$ \\
\hline \multicolumn{3}{|l|}{ Togaviridae } \\
\hline \multirow[t]{6}{*}{ Alphavirus } & Chikungunya & Unidentified bat \\
\hline & Sindbis & $\begin{array}{l}\text { Pool of roundleaf bat } \\
\text { (Hipposideros sp.) } \\
\text { and horseshoe bat } \\
\text { (Rhinolophus sp.) }\end{array}$ \\
\hline & Cabassou (VEE V) & Unidentified bat \\
\hline & $\begin{array}{c}\text { Venezuelan equine } \\
\text { encephalitis (VEE) IA-B }\end{array}$ & $\begin{array}{l}\text { Common vampire bat } \\
\text { (D. rotundus) }\end{array}$ \\
\hline & VEE (IE) & $\begin{array}{l}\text { Common tent-making bat } \\
(U . \text { bilobatum })\end{array}$ \\
\hline & VEE (IF) & $\begin{array}{l}\text { Seba’s short-tailed bat } \\
\text { (Carollia perspicillata) }\end{array}$ \\
\hline \multicolumn{3}{|l|}{ Totiviridae } \\
\hline Totivirus & Tianjin totivirus & Faeces from unidentified bats \\
\hline
\end{tabular}

$a$ : adapted with permission from Calisher (2015); $b$ : many of the viruses listed in this Table were first isolated from sources other than bats. The bat hosts listed here are those from which these viruses were first obtained or otherwise detected. Note that certain of the viral nucleic acid sequences detected have been identified to virus family or to genus, but not to species, thus this is a provisional list; $c$ : vernacular names of bats follow primarily Wilson and Reeder (2005). Some of these viruses or sequences have now been detected in bats of other species. 
Rabies - No review concerning bats and viruses can be complete without at least a brief summary of this first virus recognised in bats and the classical account of the disease it causes. Numerous books and scientific publications are in print or otherwise available which provide details regarding Louis Pasteur's efforts to devise a vaccine against the disease called rabies (L. rabies, rage, madness). Classical rabies virus (street rabies) is the prototype virus of a complex of viruses that have been detected in bats, dogs and other mammals. This negative sense, single-stranded RNA virus has been classified in the virus order Mononegavirales, family Rhabdoviridae (Gr. rhabdos, rod) and genus Lyssavirus (Gr. lyssa, rage, fury, canine madness).

Rabies may be the oldest human infectious disease known. Its origin has been associated with wolves [Canis lupus (Carnivora, Canidae)], now domesticated as $\operatorname{dogs}(C$. lupus familiaris). Even as far back as $2300 \mathrm{BC}$ dog owners in the Babylonian city of Eshnunna were fined for deaths caused by their dogs having bitten people. In $500 \mathrm{BC}$, the Greek philosopher Democritus described a case of canine rabies. In $400 \mathrm{BC}$, Aristotle wrote 'dogs suffer from the madness. This causes them to become very irritable and all animals they bite become diseased', In the first century, Roman writer Cardanus described the saliva from a rabid dog as a 'virus' (L. virus, poison). In 1804, a German scientist, Georg Gottfried Zinke, demonstrated that rabies could be passed through saliva from rabid dogs.

Nonetheless, the geographic distribution of all haematophagous bats (vampire bats), either extant or fossil, are restricted to the New World tropics (Koopman 1994). For whatever reasons, whether brought to the New World or because Trinidad and Tobago and Haiti were foci of rabies and inferred associations of rabies and bats, the mythology and superstitions encompassing bats served as an impediment to research on bats and on infectious diseases. To some extent, though considerably lessening, this remains true.

It was Antonio Carini (1911) - an Italian physician, bacteriologist and professor and director of the Pasteur Institute of São Paulo - who presented findings that rabies of herbivores could be transmitted by bats. Howev$\mathrm{er}$, the first isolation of rabies virus was from a common vampire bat [Desmodus rotundus (Phyllostomidae)] in 1931 (Baer 1991). The same conclusion drawn by Carini was made by Lima (1934), also in Brazil, and Pawan (1936), in Trinidad; the latter also made the connection between fruit-eating bats and paralytic rabies (Pawan 1948). These studies truly turned the direction of rabies, virus and bat research forward, but it was not until relatively recently that other viruses and bats themselves came into prominence, as mentioned below.

In 1903, Adelchi Negri, an Italian physician, reported his observations of what came to be called 'Negri bodies', eosinophilic inclusions found in the cytoplasm of nerve cells containing rabies virus (Negri 1903). Remarkably, it was not until 1953 that the first American case of rabies in a bat was reported from Pennsylvania (Witte 1954). For many years thereafter, diagnostic techniques began to be improved, epidemiologic investigations expanded, specific monoclonal antibodies produced and applied and investigations of rabies virus put on a molecular basis, but the primary advance in rabies diagnosis was the development of an immunofluorescence test in the 1950s, used to detect rabies virus antigens (Goldwasser \& Kissling 1958).

Rabies virus-related viruses - Other rhabdoviruses have been isolated from bats (Calisher \& Ellison 2012). Aravan virus has been isolated from a lesser mouseeared bat [Myotis blythii (Vespertilionidae)] in Kyrghyzstan, Central Asia, Australian bat lyssavirus, from black (Pteropus alecto), gray-headed (Pteropus poliocephalus), little red (Pteropus scapulatus) and spectacled (Pteropus conspicillatus) flying-foxes (Pteropodidae) and yellowbellied pouched bats [Saccolaimus flaviventris (Emballonuridae)], in Australia, Bokeloh virus from a Natterer's myotis [Myotis nattereri (Vespertilionidae)] in Germany, Duvenhage virus, from Schreibers's long-fingered bat [Miniopterus schreibersii (Miniopteridae)] and Egyptian slit-faced bat [Nycteris thebaica (Nycteridae)] in South Africa, European bat lyssavirus 1, from common serotines [Eptesicus serotinus (Vespertilionidae)], European bat lyssavirus 2, from Daubenton's bats [Myotis daubentonii (Vespertilionidae)], Irkut virus, from greater tube-nosed bats [Murina leucogaster (Vespertilionidae)] in Russia and China, Khujand virus, from a whiskered myotis [Myotis mystacinus (Vespertilionidae)] in Tajikistan, Lagos bat virus, first isolated from a African straw-coloured fruit bat [Eidolon helvum (Pteropodidae)] in Nigeria, Lleida bat lyssavirus, from Schreibers's long-fingered bat in Spain, Shimoni bat virus, from a Commerson's leaf-nosed bat [Hipposideros commersoni (Hipposideridae)] in Kenya and West Caucasian bat virus, from a Schreibers's long-fingered bat in Russia. Mokola virus, although not isolated from bats, also is a member of the rabies-virus related virus group and has been isolated from shrews [Crocidura spp (Soricomorpha, Soricidae)] and domestic cats in Nigeria. Since the initial detections of these viruses, with the exception of Mokola virus, most have been detected in bats of species other than those mentioned above. Among those mentioned above, only pteropodids feed on plants, whereas all others feed on animals, including insects, other invertebrates or vertebrates.

Severe rabies-like disease in humans has led to additional studies of flying-foxes, resulting in a greater understanding of the epidemiology and geographic distribution of Australian bat lyssavirus. Based on this evidence, Fraser et al. (1996) suggested that bats may play a more important role in the circulation of virus diseases than had been previously realised.

Hendra, Nipah and other paramyxovirus diseases - Hendra and Nipah viruses are both highly pathogenic zoonotic paramyxoviruses (Mononegavirales, Paramyxoviridae) that have been detected in pteropodid bats within the last decades (Marsh et al. 2012). A horse died of undiagnosed cause in 1994 in Queensland, Australia. Eight to 11 days later depression, anorexia, fever, dyspnoea, ataxia, tachycardia, tachypnoea and nasal discharge was reported in 17 other horses from the same area; 14 of them died or were euthanised. Five and six days, respectively, after the death of the index horse, a stable hand and 
a horse trainer, both of whom had had close contact with the sick horse's mucous secretions, were diagnosed with influenza-like illnesses. The stable-hand recovered, but the trainer developed pneumonitis, respiratory failure, renal failure and arterial thrombosis and succumbed from cardiac arrest seven days after admission to hospital. A paramyxovirus cultured from his kidney was shown to be identical to viruses isolated from the lungs of five affected horses. The two affected humans and the horses had antibody to the virus and the disease was reproduced in healthy horses following challenge with spleen-lung homogenates from infected horses (Selvey et al. 1995). Scattered other cases caused by this virus were identified, but evidence for its otherwise occurrence were not obtained by testing vertebrates and arthropods in the associated areas until flying-foxes were tested and the virus isolated from blood, foetal tissues, uterine fluids, urine, faeces and saliva (Halpin et al. 2000).

The etiologic agent eventually was named Hendra virus after the Queensland location where the first cluster of cases occurred. More than one-fifth of the flyingfoxes in eastern Australia were shown to have neutralising antibody to Hendra virus, as did bats of multiple species of flying-foxes in New Guinea. In 1996 Hendra virus was isolated from a flying-fox (Halpin et al. 2000). Epidemiologic evaluations suggested that horses become infected with Hendra virus via direct or indirect contact with infected flying-foxes and humans become infected with this virus via direct contact with infected horses. Disease control has been made by preventing contact between flying-foxes and horses.

A second paramyxovirus detected in flying-foxes is Menangle virus (genus Rubulavirus), responsible for a 1997 zoonotic disease affecting pigs and humans in New South Wales, Australia. Antibodies capable of neutralising Menangle virus were detected in flying-foxes, providing provisional evidence of a bat origin for this virus; the virus later was isolated from black flying-foxes (Barr et al. 2012). Samples of Indonesian bats have revealed the presence of henipavirus and rubulavirus RNAs.

In 1998 yet another paramyxovirus, this one named Nipah virus, was recognised as the etiologic agent of a fatal disease of humans and pigs in Malaysia and Singapore (Chua et al. 2000). By June of the following year more than 100 fatalities among 250 human encephalitis cases were diagnosed in Malaysia and another 11 cases, including one fatality, were diagnosed in Singapore. Initially misdiagnosed as an epizootic of Japanese encephalitis, precious time was lost in controlling this epizoodemic. Control efforts eventually included culling of all pigs on affected farms, an extremely costly measure resulting in the near collapse of the billion-dollar pigfarming industry, heightened animosity between communities and elevated administrative costs in Malaysia.

Nipah virus was shown to be closely related to Hendra virus of Australia (Chua et al. 2000) and, because of their large genomes, their limited homologies with other paramyxoviruses and other unique characteristics, these two viruses were placed in a separate genus (Henipavirus) of the family Paramyxoviridae. Because of the similarity of Nipah and Hendra viruses, flying-foxes were suspected as being somehow involved in the epide- miology of Nipah virus. Neutralising antibodies to Nipah virus were detected in pteropodid bats of five species in Malaysia, suggesting widespread infection in bats there. Soon thereafter the virus was detected in urine of variable flying-foxes (Pteropus hypomelanus) and in fruits partially eaten by them, confirming these bats as natural hosts of the virus (Chua et al. 2002). Taken together, the epidemiologic portrait was that climatic and humandriven ecologic changes and locations of pig farms in orchards, which are home to fruit bats, provided settings in which Nipah virus can switch species, from fruit bats to pigs to humans. Nipah virus also has been associated with Lyle's flying-fox [Pteropus lylei (Pteropodidae)] in Cambodia (Reynes et al. 2005) and pteropodids and hipposiderids in Thailand (Wacharapluesadee et al. 2005).

In early 2001, an outbreak of febrile illness associated with altered sensorium was observed in Siliguri, West Bengal, India; laboratory investigations did not immediately identify an infectious agent. Nipah virus infection had not been previously detected in India, but because Siliguri is near the border with Bangladesh, where outbreaks of Nipah virus infection had recently been reported, samples obtained during the Siliguri outbreak were retrospectively analysed for evidence of Nipah virus infection. Nipah virus-specific IgM and IgG antibodies were detected in nine of 18 patients. Reverse transcriptase-polymerase chain reaction assays detected Nipah virus RNA in urine samples from five patients. Sequence analysis confirmed that the Nipah virus from humans in Siliguri was more closely related to Nipah virus isolates from Bangladesh than to Nipah virus isolates from Malaysia (Chadha et al. 2006).

In contrast to transmission of Nipah virus from bats elsewhere, transmission in Bangladesh was found to be via drinking the sap of date palms [Phoenix dactylifera (Arecales, Arecaceae)] and via person-to-person route. Nipah virus RNAs detected in Bangladesh are variable in their sequences, suggesting multiple introductions via Indian flying-foxes Pteropus giganteus (Pteropodiae), which migrate long distances and are found in the Maldives, India, Bangladesh, China, Nepal, Pakistan and Sri Lanka.

RNA of Cedar virus, another henipavirus, was detected in urine of pteropodid bats in Australia in 2009, but little is yet known about this virus (Marsh et al. 2012). Challenge studies with Cedar virus in domestic ferrets [Mustela putorius furo (Carnivora, Mustelidae)] and domesticated guinea pigs [Cavia porcellus (Rodentia, Caviidae)], both susceptible to infection and disease with known henipaviruses, confirmed virus replication and production of neutralising antibodies, but no clinical disease. Also, the major genetic difference between $\mathrm{Ce}-$ dar virus and Hendra and Nipah viruses lies within the coding strategy of the P gene, known to play an important role in evading the host innate immune system. Preliminary studies indicated that Cedar virus infection of human cells induces a more robust interferon- $\beta$ response than does Hendra virus. Cedar virus is one that might be studied to develop a human and livestock vaccine.

Intriguing evidence for infection with a henipavirus in African bats was presented by Hayman et al. (2008) who reported finding antibody to henipaviruses in African straw-coloured fruit bats from Ghana. As a follow- 
up, Drexler et al. (2009) detected henipaviral RNA in an African straw-coloured fruit bat. Clearly, information regarding the geographic distribution and medical and veterinary importance of the henipaviruses and their relationship with bats is not nearly complete.

Severe acute respiratory syndrome (SARS) - The hundreds of human case notifications of SARS in Guangdong Province, People's Republic of China in late 2002, then elsewhere in the world, moved bat virus recognition from unanticipated and occasional to well-planned and more methodical. Thereafter the World Health Organization (WHO) put the entire world on alert. SARS cases soon were diagnosed in patients not only in Vietnam, but also in Hong Kong and Canada, and cases were diagnosed in health care workers and household members who had cared for patients with the disease. Many of the cases were traced back through chains of transmission to a health care worker from Guangdong Province who had visited Hong Kong, where he was hospitalised with pneumonia and died. By late April 2003, more than 4,000 SARS cases and 250 SARS-related deaths were reported to the WHO from more than 25 countries. Most of these cases occurred after exposure to SARS patients in health care or household settings.

The WHO coordinated a massive international collaborative effort that included clinical, epidemiologic and laboratory investigations and simultaneously initiated efforts to control the spread of the disease. Attempts to identify the causative agent of the outbreak were successful during 2003, when laboratories in the United States of America (USA), Canada, Germany and Hong Kong isolated a novel CoV (SARS CoV) from SARS patients. Classified as a virus in the order Nidovirales, family Coronaviridae and genus $\mathrm{CoV}$, unlike other human CoVs, this one can be isolated in Vero cells. SARS CoV RNA has frequently been detected in respiratory secretions and convalescent-phase serum specimens from SARS patients contain antibodies that react with SARS CoV, altogether providing evidence that it was a newly recognised virus and associated with the disease. The source of the virus in nature had not been determined at that time, but knowing it was a $\mathrm{CoV}$ made the search easier.

CoVs comprise a diverse group of large, enveloped, positive-stranded RNA viruses that cause respiratory and enteric diseases in humans and other animals. Their genomes are the largest (about 30,000 nucleotides) of any RNA virus known. A great deal is known about CoVs, nicely summarised by Ksiazek et al. (2003) and Rota et al. (2003) in their papers describing molecular and other characteristics and properties of SARS CoV and comparing its genome to the genomes of other CoVs.

Many possible natural history scenarios - among others, human infections originating with masked palm civets [Paguma larvata (Carnivora, Viverridae)] and raccoon dogs [Nyctereutes procyonoides (Carnivora, Canidae)] in live markets of wild animals in mainland China - were proposed, but were more confusing than helpful to our understanding of the origin and spread of the virus. Poon et al. (2005), searching for the SARS $\mathrm{CoV}$ in Hong Kong bats, came close to succeeding, being the first to detect a $\mathrm{CoV}$ (group 1, i.e., alphacoro- naviurs) in bats; a retrospective study of samples collected for other purposes demonstrated the presence of an alphacoronavirus RNA sequence in an Australian bat captured in 1996 (LL Poon, unpublished observations). Then Lau et al. (2005) and Li et al. (2005) reported detections of (group 2, i.e., betacoronavirus) SARS CoVlike viruses in bats, thus providing evidence that bats are a natural source of at least some of the numerous alphacoronavirus and betacoronavirus found world-wide (Osborne et al. 2011). By now, partial descriptions of many hitherto unrecognised coronaviral sequences have been published in the scientific literature. Without more biological and epidemiological information it is difficult to determine whether these represent newly recognised viruses, are closely or distantly related strains or are more items to add to lists; these are not tabulated in Table II. Obviously, evidence of the presence of many important viruses in bats has served to invigorate studies of the biology of bats themselves as well as the discovery of disease-associated viruses.

Middle East respiratory syndrome (MERS) - MERS is caused by a CoV called MERS CoV. Cases of this disease were first reported from Saudi Arabia by ProMED and formally published soon after (Bermingham et al. 2012). MERS affects the respiratory system and most MERS patients develop severe acute respiratory illness with fever, cough and shortness of breath. The case-fatality rate of MERS is about $45 \%$. Through retrospective investigations, health officials later showed that the first known cases of MERS occurred in Jordan in 2012. Thus far, all cases of MERS have been linked to countries in and near the Arabian Peninsula. This virus has spread from ill people to others through close contact, such as caring for or living with an infected person. As of 23 January 2015, there have been 956 laboratory confirmed cases of MERS CoV infection, including 351 deaths, a large proportion of whom had pre-existing co-morbidities. Because of its similarity to the SARS CoV, it had been anticipated that bats were somehow involved in transmission of the MERS CoV and Memish et al. (2013) detected a partial RNA sequence of a betacoronavirus with $100 \%$ identity to virus from the human index casepatient. This nucleotide sequence was obtained from a faecal pellet from an Egyptian tomb bat [Taphozous perforatus (Emballonuridae) (Memish et al. 2013)] in Saudi Arabia, and a close relative of this virus was detected in a Zulu serotine bat [Neoromicia $\mathrm{cf}$. zuluensis (Vespertilionidae)] by Ithete et al. (2013) in South Africa. However, recent studies have suggested that one-humped camels [Camelus dromedarius (Artiodactyla, Camelidae)] may be a primary source of this virus in nature (Raj et al. 2014) and experimental infections of camels with MERS $\mathrm{CoV}$ seem to support this view (Adney et al. 2014). MERS CoV continues to cause disease in the Arabian Peninsula, but is not expected to cause a pandemic.

Marburg and ebolavirus haemorrhagic fevers - Marburg and ebolaviruses - (Mononegavirales, Filoviridae), genera Marburgvirus and Ebolavirus, respectively, the 'filoviruses' - were discovered because they cause severe, often fatal, haemorrhagic diseases in humans and other primates. 
Marburgvirus disease - In late summer of 1967, an haemorrhagic fever outbreak was observed in laboratory workers in Serbia, at the time part of Yugoslavia and in Germany. It was soon shown that the disease was transmitted from green monkeys [Chlorocebus sabaeus (Primates, Cercopithecidae)] consigned from Uganda to Europe, but the origin of the disease was unknown, other than that it was caused by a hitherto unrecognised virus, named Marburg virus for the city in Germany where the disease was first recognised. Another infection with this virus occurred in a traveller in Africa in 1975 and cases of Marburg haemorrhagic fever have been documented with some frequency in various parts of Africa since then. Although a great deal was learned about this virus from pathologic and laboratory studies, its epidemiology remained undetermined. Nonetheless, bits and pieces of evidence suggested that bats might be associated with Marburg virus. It was not until 1999 that Swanepoel et al. (2007) detected Marburg virus RNA in Egyptian rousettes, eloquent horseshoe bats [Rhinolophus eloquens (Rhinolophidae)] and a greater long-fingered bat [Miniopterus inflatus (Vespertilionidae)] captured in the Democratic Republic of the Congo and Towner et al. (2009) isolated genetically diverse Marburg viruses from Egyptian rousettes. Marburgviruses are now placed in the genus Marburgvirus, species Lake Victoria marburgvirus.

Ebolavirus diseases - In 1976, a series of severe and often fatal haemorrhagic fevers occurred in southern Sudan. Almost immediately after those cases were recognised, a similar disease was observed in humans in Zaire, now known as the Democratic Republic of the Congo, nearly $1,000 \mathrm{~km}$ away. A virus, originally termed 'Ebola virus', named after the Ebola River near the epidemic site in Zaire, was isolated from patients in Zaire and partially characterised (Johnson et al. 1977) but, as with Marburg virus, early intensive field studies did not reveal the source of the virus. The virus detected in Zaire eventually was named Zaire ebolavirus and the distinct virus from Sudan was named Sudan ebolavirus.

A third ebolavirus, Reston ebolavirus, was discovered in 1989 when an outbreak of anorexia, nasal discharge, splenomegaly and haemorrhaging was recognised among crab-eating macaques [Macaca fascicularis (Primates, Cercopithecidae)] imported from a commercial source in the Philippines to a primate holding site in Reston, Virginia, USA. No human illnesses among animal handlers were recognised (Jahrling et al. 1990). Then, in 1994, clinical investigations into the haemorrhagic illnesses and deaths of common chimpanzees [Pan troglodytes verus (Primates, Hominidae)] in the Taï Forest of Côte d'Ivoire resulted in an accidental infection and non-fatal illness of an investigator performing a necropsy on one of these primates. Virus isolation from this patient was successful and the virus named Taï Forest ebolavirus. The cause of deaths of the members of the chimpanzee group was later shown to be infection with this virus. This was the first time that a human ebolavirus infection had been connected to naturally-infected non-human primates in Africa (Le Guenno et al. 1995).

Epidemiologic and virologic investigations of an epidemic of haemorrhagic fever in humans in western
Uganda in 2007 revealed the cause as being Bundibugyo ebolavirus, named for the district in Uganda where the epidemic occurred. This virus is more closely related to Taï Forest ebolavirus than it is to other ebolaviruses, but is distinct from them all (Towner et al. 2008).

In sum, since 1967 filoviruses have been the cause of very serious and focal or widespread haemorrhagic fever outbreaks in Africa, as well as in the USA, although the latter experience was limited to imported monkeys. Most of the haemorrhagic fever outbreaks or epidemics have had case-fatality rates of $50-90 \%$. The identified index cases in these situations have been shown to have been in contact with ebolavirus-infected primates or other large vertebrates, either killed or found dead in forested areas. Because bats have been shown to harbour various filoviruses and because they are used as protein sources by human and free-ranging non-human-primates in some parts of Africa, Asia and perhaps elsewhere, eating and other contacts with an ebolavirus may result in virus transmission and epidemic initiation. The validity of such a scenario remains to be proven.

A novel filovirus, provisionally named Lloviu virus (the only virus in the genus Cuevovirus), was detected during the investigation of bat die-offs in Cueva del Lloviu in Spain in 2002. Lloviu virus is genetically distinct from marburgviruses and ebolaviruses and is the first filovirus detected in Europe that was not imported from an endemic area in Africa. Whereas infections of bats with marburgviruses and ebolaviruses do not appear to be associated with disease in the bats, Lloviu virus was detected in a dead Schreibers's long-fingered bat.

Survival of bats from experimental infections led Swanepoel et al. (1996) to list Wahlberg's epauletted fruit bats [Epomophorus wahlbergi (Pteropodidae)], little free-tailed bats [Chaerephon pumilus (Molossidae)] and Angolan free-tailed bats [Mops condylurus (Molossidae)] as potential hosts for Zaire ebolavirus. In addition, from 2001 and 2003, Leroy et al. (2005) collected small vertebrates at sites where non-human primates had died at the border between Gabon and the Republic of the Congo. They detected RNA of an ebolavirus in hammerheaded fruit bats (Hypsignathus monstrosus), Franquet's epauletted fruit bats (Epomops franqueti) and little collared fruit bats (Myonycteris torquata). These RNA sequences were quite similar to those of the ebolavirus isolated from humans during the 1976 outbreak in Zaire. Other investigations led to antibody detections in bats of the same species. Leroy et al. (2005) detected ebolaviral RNA from them and from other pteropodids and molossids as well (Olival \& Hayman 2014). This has been the ostensible link for an association of bats with Zaire ebolavirus and confirmed their speculation that ebolaviruses circulate in the forests of Central Africa (Leroy et al. 2005). The West African ongoing outbreak that is ravaging Guinea, Liberia and Sierra Leone, initiated more than one year ago, has sickened more than 20,000 people and killed more than 8,000 of them to date. Although these countries are geographically closer to the Ivory Coast than the Democratic Republic of Congo and South Sudan, Baize et al. (2014) demonstrated that this strain is phylogenetically closer to the Zaire ebolavirus than is the Taï strain. Gire et al. (2014) provided support 
for this hypothesis, their data suggesting that the West African variant diverged from the Zaire ebolavirus (central African lineage) about 2004.

Based on the work of Leroy et al. (2005), frugivorous bats were tentatively linked to the ongoing outbreak in West Africa (Baize et al. 2014), but field investigations raised a new scenario for the emergence of the virus. According to Saéz et al. (2015), the index case (a 2-yearold boy from the small village of Meliandou, Guinea) may have been infected by playing in a hollow tree used to house a colony of Angolan free-tailed bats - a species widespread in Central and West Africa. The tree was burned and the colony no longer lives in the hollow. During field investigations Saéz et al. (2015) found no infected bats; however, Angolan free-tailed bats are among those that have survived experimental infections (Swanepoel et al. 1996). Thus, the accumulated evidence, while implicating bats in transmission of many viruses, may only be coincidental and remains unproven.

\section{Bat immunology}

In addition to their other well-known uniquenesses, it may be asked whether bats have unique responses to virus infections. That is, why (or how) do bats survive infections with viruses and other agents that are pathogenic for other vertebrates? Or do they? These questions have not been answered satisfactorily and data accumulated thus far have not definitively answered them, but have led to speculation, much of which is fascinating. Serologic studies demonstrated that bats have antibody to many viruses, but it was not determined whether their antibody isotypes were similar to those of other mammals. Nearly 50 years ago, for example, Sulkin et al. (1966) maintained big brown bats [Eptesicus fuscus (Vespertilionidae)] experimentally infected with Japanese encephalitis virus at various environmental temperatures and then tested them for both virus and neutralising antibody. Viraemias were demonstrable in most of these bats within two-three days after infection and persisted for one-two weeks. However, not all viraemic bats produced antibody to the virus, a few others had equivocal and then delayed (nearly 2 months) antibody responses and some that had produced antibody soon after being infected no longer had detectable antibody three months later.

We know that bats produce $\operatorname{IgM}, \operatorname{IgG}, \operatorname{Ig} \mathrm{A}$ and $\operatorname{IgE}$ antibodies, but not whether these bat immunoglobulins react as do similar immunologic isotypes of other vertebrates. There are clear differences between bats of different species. For example, only a single IgG subclass has been identified in Seba's short-tailed bats [Carollia perspicillata (Phyllostomidae)], whereas little brown myotis [Myotis lucifugus (Vespertilionidae)] have five IgG subclasses (Butler et al. 2011). One can conclude from this that bats of different species differ, which is not enlightening taxonomically, but is informative in regard to the danger of making generalisations about bats.

Now that bats have been shown to host hundreds of viruses, some of them important pathogens of humans, interest in and studies of the immunological responses of bats has increased; data accumulated recently have been fascinating and informative (Baker et al. 2013a, Epstein et al. 2013, Zhang et al. 2013). Baker et al. (2013b) have nicely reviewed the literature concerning antiviral immune responses in bats and the reader is encouraged to see that publication.

Dead or sick bats have been the source of viruses of bats (Supplementary Table II), but these have principally been focused on rabies virus because of the importance of that virus and because of the attendant emphasis on studies of its occurrence, geographic distribution and genotype. Finding dead or sick bats with other viruses is not a common occurrence, likely due to the rapid scavenging of dead animals under natural conditions, although meticulous searching may indicate otherwise (Mühldorfer et al. 2011). Such studies may provide information useful to our understanding of sex differences, seasonality and other aspects of the prevalence of viruses in bats. Even the highly pathogenic rabies virus has been detected in apparently healthy bats (Davis et al. 2012). How rabies virus and other viruses persist over time certainly depends on a mechanism for such persistence, but that mechanism is unclear at this time, although it is being slowly revealed (Blackwood et al. 2013).

Nonetheless, it is unusual to find dead or sick bats. That at least some viruses have been detected in apparently healthy bats, which must be netted or otherwise sampled in the field, has led to hypotheses that centre on the possibility that bats somehow tolerate at least certain virus infections and this has encouraged investigators to question whether bats can allow virus infections, remain asymptomatic, yet respond to such infections differently from the ways in which other mammals respond to them.

In an effort to provide a foundation for understanding adaptations by bats that might allow them to at least somewhat peacefully coexist with viruses that infect them, Papenfuss et al. (2012) assembled transcriptome sequences from immune tissues and cells of black flying-foxes. They identified 18,600 genes, of which 650 (3.5\%) corresponded to immune genes and about 500 of which were identified, providing information regarding innate and adaptive immunity of these bats. These and other results suggested that bats have many genes consistent with those in available databases, but which may represent bat-specific transcripts. Alternatively, a transcriptome data set of Shaw et al. (2012) representing Jamaican fruit-eating bats [Artibeus jamaicensis (Phyllostomidae)] differs somewhat from that of Papenfuss et al. (2012), indicating yet another difference between bats of different species.

Other studies of bat genomes have indicated differences in genes associated with early immune responses, which might allow virus to replicate in the absence of a primary and hearty immunological response. It is further reasonable to assume that this in turn might allow at least low-level virus replication over an extended period. There is some evidence that these genes may be evolving more rapidly in bats than in vertebrates of other taxa, which would suggest that the genes are co-evolving with the bats in response to viral and other infections. An additional note of caution: when studying viruses from bats in order to understand their effects, it is clearly more ap- 
propriate to use bats or their cells in culture, rather than other hosts or cells from other hosts. That is, simply because a virus or other pathogen might interfere with or activate a gene product in one host, there is no certainty that it does the same in another host; thus the extrapolatory and speculatory nature of many available publications. A recent paper by Zhang et al. (2012) provides a new insight into the interplay between bat host and infecting virus. The authors isolated a novel $\beta$-herpesvirus from a Schreibers's long-fingered bat and, in determining its complete DNA genome sequence, found it to be the first virus genome known to encode major histocompatibility complex (MHC) class II homologues. The authors proposed future functional studies of these MHC class II homologues to determine whether they may play a role in potentially novel virus immune evasion pathways (Zhang et al. 2012). This remarkable finding may change the way we view both bats as hosts and viruses as pathogens.

Humans and most other mammals respond to infections by activating their immune systems at the time they are infected, usually producing type I and type III interferons, which are temporising responses activated prior to humoral antibody responses. The immune systems of bats of at least one species (black fling-fox), on the contrary, appear to be perpetually switched on at a low level, thus allowing them to respond quickly to an infectious agent (Zhou et al. 2014). Alternatively, bats may have a potent innate or inherent immunity, one that is more efficient in restricting viral replication or even restricting innate immunity (Siu et al. 2014).

Hibernation - the state of inactivity in which the heart rate, body temperature and breathing rate are decreased in order to conserve energy - has been put forth as a contributor to viral persistence in bats. Bouma et al. (2010) have summarised the physiological and immunological effects of hibernation as also including depressed metabolism, lower numbers of circulating leukocytes, lower complement levels, decreased response to lipopolysaccharides and lower phagocytotic capacity, cytokine production, lymphocyte proliferation and antibody production. They suggest that hibernation may increase infection risk in bats. Further, it has been proposed that the rapid reestablishment of immune responses in bats emerging from hibernation and infected with the white-nose syndrome fungus, Pseudogymnoascus destructans (Ascomycota, Pseudeurotiaceae), may bring about a severe immune reconstitution inflammatory syndrome (Meteyer et al. 2012).

Hibernation also may allow not only virus persistence in the bat, but trans-seasonal persistence as well, allowing virus to amplify and re-emerge when conditions are more amenable to transmission, such as seasonally for arthropod-borne viruses, colony formation and movement to maternity caves.

\section{Concluding remarks}

Bats and emerging viruses - More than 200 viruses of 27 families were isolated from or detected in bats of both suborders. A few of these viruses have been responsible for human diseases, including isolated events or disease outbreaks that have resulted in human deaths and bats have been tentatively blamed for some of these episodes (e.g., ebolavirus disease, SARS, MERS). Because bats represent such a large proportion of mammals (about $20 \%$ ) and are so diversified in their biology, habitats and natural history, it seems reasonable to assume that they have many hundreds more viruses, just as do other diversified groups of life forms. A few hypotheses have been raised to explain so many viruses in bats (O'Shea et al. 2014, Brook \& Dobson 2015). However, as to whether these viruses are important or not, whether bats are simply incidental hosts of viruses and whether they serve as competent reservoir hosts of viruses and transmit them to other vertebrates are open questions that must be carefully addressed.

In general, the supposed connections between bats and disease outbreaks caused by zoonotic viruses have been raised more on speculation than on evidence supporting their direct or indirect roles in the epidemiology of those diseases (Fenton et al. 2006). In most cases, the only evidence is the isolation or otherwise detection of the same viruses in bats and humans in areas where the diseases have emerged, but this does not mean that bats are the hosts for the viruses. The identification of the same virus in bats and humans might only be evidence that as mammals they are similar enough to serve as temporary hosts for the virus and the same virus can also be found in other terrestrial vertebrates (e.g., primates, antelopes, birds) and arthropods (Calisher et al. 2006, Melaun et al. 2014). As an example, Ross River virus has been isolated from gray-headed flying-foxes, but these bats did not produce viraemia of sufficient magnitude to be considered competent reservoir hosts for this virus (Ryan et al. 1997). Alternatively, Seymour et al. (1978a) detected specific antibodies of Venezuelan equine encephalitis virus in bats of seven different species from Guatemala. Based on this evidence, Seymour et al. (1978b) experimentally infected bats of five species. Viraemia was detected in most bats, but all were asymptomatic for the infection. They concluded that the phyllostomids Jamaican fruiteating bats, great fruit-eating bats (Artibeus lituratus) and little yellow-shouldered bats (Sturnira lilium) had circulating virus levels high enough to infect culicid mosquitoes (Diptera, Culicidae) that may serve as vectors for the virus, whereas great spear-nosed bats [Phyllostomus hastatus (Phyllostomidae)] did not develop sufficient viraemia to infect subsequently feeding mosquitoes (Seymour et al. 1978b). Based on these results, we can speculate that there is variability of the immune responses of bats to virus infections, particularly in representatives of closely related species.

Among the scores of viruses and viral sequences identified from bats (Table II), several have been isolated or detected in bat tissues or excreta. However, this does not prove a relationship between the presence of a virus (or its nucleic acid sequence, albeit a nucleotide sequence is not a virus) and the disease the virus might cause. Some of these viruses or viral sequences might have been in food eaten by bats and at least some (or most) are irrelevant with respect to viral disease epidemiology.

Because of the many gaps in our knowledge linking bats and zoonotic viruses, associating bats with these events without any further evidence is a disservice, with negative consequences for bats and humans. For bats, be- 
cause it puts them on target for 'control' and it disseminates fear among the general public. For humans, because putting efforts to control the wrong reservoir or disease carrier can postpone appropriate mitigation actions that could avoid more deaths or interrupt the spread of the disease and because a potential 'control' of bat populations may deny us their important ecosystem services.

As mammals, bats share many physiological and immunological traits with humans. Additionally, they are in constant contact with humans, with bats of different species roosting in human-made constructions, feeding or hanging on fruit trees or flying around light poles to feed on insects in urban and rural areas. These habits increase their contact with humans, domestic animals, livestock and wildlife, potentially favouring spillovers.

After analysing most of the disease outbreaks that have been tentatively linked to bats, it is obvious that there are at least two transmission routes: from bats directly to humans and from bats to humans through intermediate hosts or vectors. The first one seems to be possible via bites during occasional interactions with bats in roosts or bats on the ground (Saéz et al. 2015) and through contact with bat fluids during capturing and preparing them as food (apes, other primates and carnivores can be infected while feeding on bats). However, transmission by contact or ingestion of infected droppings in bat roosts cannot be discounted (Saéz et al. 2015), inasmuch as viruses or viral nucleic acid sequences have been retrieved from urine and faeces of bats (Halpin et al. 2000). The disease caused by the Zaire ebolavirus is a potential example of this route.

Virus transmission from bats to humans through intermediate hosts seems reasonably and logically the link to explain the outbreaks of Nipah and Hendra diseases. However, one aspect of these links has been overlooked. Only animals phylogenetically closer to bats appear as intermediate hosts. Most spillover episodes had horses and pigs linking bats and humans. In other events, camels and carnivores (ferrets, palm civets and raccoon dogs) also figure among the mammals in which viruses apparently circulate. Except for humans, these mammals are from groups that have evolved within the superorder Laurasiatheria. Horses are representatives of the order Perissodactyla, pigs and camels are in the order Artiodactyla and ferrets, palm civets and raccoon dogs are in the order Carnivora; all are members of the superorder Laurasiatheria.

Although bats have been distinct from other mammals for more than 52 million years, bats, carnivores perissodactyls and artiodactyls share part of their evolutionary history that is not shared with other mammals and their ancestors may have co-evolved with ancient lineages of certain viruses. This suggests that they may share physiological characteristics that could facilitate circulation of these viruses. Dobson (2006) visited pig farm sites where outbreaks of Nipah virus infections occurred in Malaysia and found partially eaten fruits with bat teeth marks in them. According to Dobson (2006), pigs may have been contaminated by eating fruits that had been partly eaten by bats and subsequently passed the virus to humans. This hypothesis was tentatively rejected by Fenton et al. (2006) based on the argument that

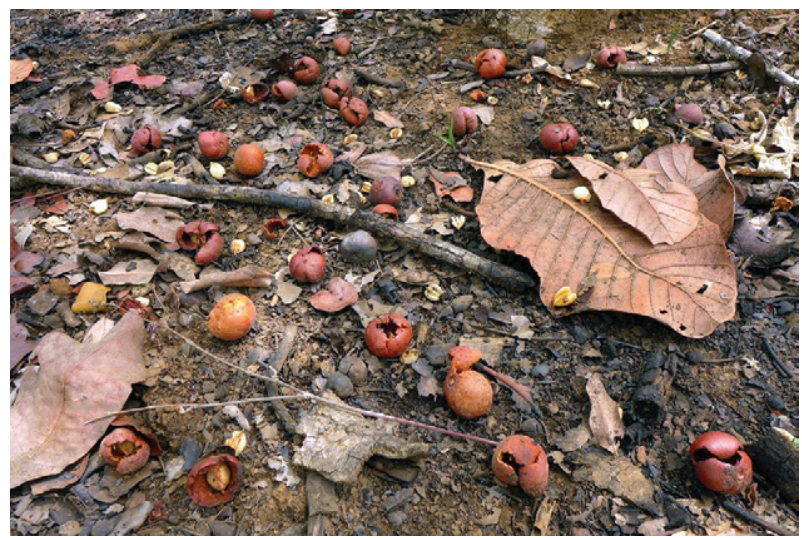

Fig. 3: sugar plum (Uapaka kirkiana; Phyllanthaceae) with bat tooth marks on fruits husks, Zambia. Courtesy of Jakob Fahr (Max Planck Institute for Ornithology, Germany), the copyright holder of the image.

pellets rejected by frugivorous bats are composed of indigestible fibres and seeds that have little nutritional value for animals. However, one of us (RM) several times has found on the ground fruits that had been partially eaten by bats (e.g., Fig. 3); there is no reason to believe that other frugivorous or omnivorous mammals, such as primates and carnivores, do not feed on them. Given that Chua et al. (2002) detected Nipah virus in fruits partially eaten by variable flying-foxes, this general scenario seems very reasonable. Using Dobson's (2006) hypothesis as a background, pigs became infected with Nipah virus by eating virus-contaminated fruits and then humans became infected by spillover from pigs, which may have occurred by contact with massive quantities of viruses in the mucosae, faeces or excreta of infected animals. Haematophagous insects may also be virus vectors. Melaun et al. (2014) provided an extensive list of viruses that have been identified in bats, haematophagous insects and humans. With bats spending most of their time stationary and upside down, some of them forming large groups, they are perfect targets for feeding arthropods, particularly mosquitoes. However, it is unlikely that arthropods are important vectors of filoviruses, paramyxoviruses and many other viruses, including rabies virus, as they have not been detected in them even though millions of them have been tested. Mechanical transmission of viruses, however, is always a possibility, but is irrelevant when discussing natural hosts.

The taxonomic and geographic distribution of bats whose viruses have potentially jumped to humans is also noteworthy. Except for rabies, all episodes are in the Old World and pteropodid, hipposiderid and rhinolophid bats - representatives of families in the suborder Yinpterochiroptera - have been mostly involved (Table II, Supplementary Table II). To date, there is no direct evidence that New World bats play important roles in the transmission of zoonotic viruses, other than rabies virus, to humans. This might be caused by a sampling bias because most studies have been concentrated in the Old World tropics; but most studies are concentrated in the Old World because people and livestock are dying there 
from those diseases. However, it may not be a biased view. Differences in the evolutionary history and biology of New and Old World bats and in human behaviour may provide reasonable explanations. From an evolutionary viewpoint, Old World bats occur in a region where the mammalian fauna was established long ago and those bat lineages may have coevolved with viruses that may have been present in other groups of mammals. In this scenario, bats might have developed strategies to survive virus infections. On the other hand, the assemblage of New World mammals (in particular that from South and Central America) was dramatically reshaped about three million years ago due to the Great American Biotic Interchange (Marshall et al. 1982) and bat and virus lineages may not have had time to coevolve. In addition, all New World bats are in the suborder Yangochiroptera, whereas pteropodids, hipposiderids and rhinolophids are in the suborder Yinpterochiroptera. The basal divergence among these suborders is almost as old as the divergence of bats and other mammals (Springer et al. 2001). Thus, we speculate that bats in these two groups may have evolved distinct immunological characteristics that provide distinct responses to pathogens, with direct implications regarding their roles as hosts. From an ecological viewpoint, some pteropodid bats tend to form large aggregations that may favour virus spread, whereas New World fruit bats usually form smaller aggregations. Also, except for a few native indigenous peoples, in the New World bats are not on the menu, which is different from Africa and Asia where these animals are consumed regularly. Eating them seems not to be a problem because their meat is cooked. The problem appears to be in the contact with their infected blood and other body fluids during handling and preparing their meat. Contact with massive quantities of viruses unquestionably favours spillovers. The above suggestions here are no more than speculations pending formal assessment.

Future investigations - We still know comparatively little about the immunological and physiological systems of wild mammals of different orders. With bats being potential reservoirs of a long list of viruses (Table II, Supplementary Table II) and possibly harbouring more zoonotic viruses than mammals of any other group (Luis et al. 2013), including some deadly viruses (Wynne \& Wang 2013), it is necessary to understand the mechanisms of immune resistance that allow bats to harbour pathogens, the pathogenetic bases of infectious diseases in bats and the mechanisms underlying disease emergence (Calisher et al. 2006, Dobson 2006, Daszak et al. 2013, Mandl et al. 2015). To address these issues, it is necessary to perform eco-epidemiological field studies and laboratory experiments using bats and bat cell cultures. Bat cell lines derived from tissues of bats of different taxa and strains of laboratory animals need to be established to provide the necessary conditions for in vitro and in vivo experiments.

To develop strains of laboratory animals, several aspects of the biology, natural history and distribution of the potential models must first be considered. To diminish risks of accidental species introductions and minimise effects of potential accidental releases into the native fauna, we suggest selection of autoctone species (those from the local fauna) that have continental distributions as potential models to test enzootic (or endemic) viruses. As an example, Pallas's mastiff bats [Molossus molossus (Molossidae)] are potential models for research in South America. They are widely distributed on the continent, adapt well to human constructions and feed on insects (Nowak 1994, Eger 2008), making them easy to maintain in captivity. We suspect that under controlled conditions their reproductive rates may be maximised and, after a few generations, physiologically uniform strains could be obtained.

In addition, fieldwork is necessary to continually searching for new pathogens and to understand the mechanisms underlying the dynamics of zoonotic diseases. It is important to design field studies to understand the role of different biotic and abiotic factors affecting bat populations and pathogen circulation in bats and how these factors may favour spillovers to humans (e.g., habitat disruption, faunal poverty, climate change) (Chua et al. 2002, Parrish et al. 2008, Daszak et al. 2013, Wynne \& Wang 2013, Saéz et al. 2015).

Joining expertise from bat biologists and medical investigators, this scenario can quickly move forward to a new one in which the role of bats in the circulation of zoonotic viruses and other pathogenic agents will be at least minimally understood. After understanding the role of bats (or other animals) in the maintenance and circulation of pathogens and the mechanisms underlying the emergence of zoonotic diseases, wildlife biologists and epidemiologists should work together to develop appropriate management plans to control virus circulation and minimise risks of human infection without causing significant biases against specific animal populations. We cannot ignore the potential role of bats in the maintenance, circulation and transmission of pathogens to humans and we cannot ignore the important ecosystem services provided by these animals. Thus, the only possible approach is to develop responsible research to avoid the obstacles and keep safe both human and bat populations. In addition, wildlife biologists and medical investigators should work together to provide expertise to wildlife epidemiologists. This training could be provided by graduate programs in public health.

Finally, can we confidently link bats with emerging viruses? No, or not yet, is the qualified answer based on the evidence available. Only integrative and organised field and laboratory research, using ecological and epidemiological approaches conducted by bat biologists and medical researchers, will provide a useful and satisfactory solution.

\section{ACKNOWLEDGEMENTS}

To JPG Leite and R Lourenço-de-Oliveira [Oswaldo Cruz Foundation (Fiocruz), Rio de Janeiro (RJ), Brazil], for the invitation to write this review, to AA Filardy (National Institutes of Health, MD, USA), for reviewing the bat immunology section, to DE Wilson (Smithsonian's National Museum of Natural History, Washington DC, USA), MR Nogueira (Darcy Ribeiro North Fluminense State University, RJ) and J Fahr (Max Planck Institute for Ornithology, Radolfzell, Germany), for providing comments on previous drafts of the paper, to A Breed (Animal and Plant Health Agency, Surrey, UK), A Pol (Federal Rural University of 
Rio de Janeiro, RJ), E Rubião (self-employed contractor), Jakob Fahr (Max Planck Institute for Ornithology) and RLM Novaes (Fiocruz), for providing photographs of the animals.

\section{REFERENCES}

Adams RA 2003. Bats of the Rocky Mountain West, natural history, ecology and conservation, University Press of Colorado, Boulder, $302 \mathrm{pp}$.

Adney DR, van Doremalen N, Brown VR, Bushmaker T, Scott D, Wit E, Bowen RA, Munster VJ 2014. Replication and shedding of MERS-CoV in upper respiratory tract of inoculated dromedary camels. Emerg Infect Dis 20: 1999-2005.

Agnelli P, Maltagliati G, Ducci L, Cannicci S 2011. Artificial roosts for bats: education and research. The "be a bat's friend" project of the Natural History Museum of the University of Florence. HYS TRIX 22: 215-223.

Altringham J 1996. Bats, biology and behavior, Oxford University Press, Oxford, 262 pp.

Altringham J 2011. Bats, from evolution to conservation, 2nd ed., Oxford University Press, Oxford, xv +342 pp.

Austad SN, Fischer KE 1991. Mammalian aging, metabolism and ecology: evidence from the bats and marsupials. J Gerontol 46: B47-B53.

Baer GM 1991. The natural history of rabies, 2nd ed., CRC Press, Boca Raton, 640 pp.

Baize S, Pannetier D, Oestereich L, Rieger T, Koivogui L, Magassouba N, Soropogui B, Sow MS, Keïta S, De Clerck H, Tiffany A, Dominguez G, Loua M, Traoré A, Kolié M, Malano ER, Heleze E, Bocquin A, Mély S, Raoul H, Caro V, Cadar D, Gabriel M, Pahlmann M, Tappe D, Schmidt-Chanasit J, Impouma B, Diallo AK, Formenty P, Van Herp M, Günther S 2014. Emergence of Zaire ebola virus disease in Guinea. N Engl J Med 371: 1418-1425.

Baker KS, Suu-Ire R, Barr J, Hayman DT, Broder CC, Horton DL, Durrant C, Murcia PR, Cunningham AA, Wood JL 2013a. Viral antibody dynamics in a chiropteran host. J Anim Ecol 83: 415-428.

Baker ML, Schountz T, Wang LF 2013b. Antiviral immune responses of bats: a review. Zoonoses Public Health 60: 104-116.

Barr JA, Smith C, Marsh GA, Field H, Wang L-F 2012. Evidence of bat origin for Menangle virus, a zoonotic paramyxovirus first isolated from diseased pigs. J Gen Virol 93: 2590-2594.

Bermingham C, Chand MA, Brown CS, Aarons E, Tong C, Langrish C, Hoschler K, Brown K, Galiano M, Myers R, Pebody RG, Green HK, Boddington NL, Gopal R, Price N, Newsholme W, Drosten C, Fouchier RA, Zambon M 2012. Severe respiratory illness caused by a novel coronavirus in a patient transferred to the United Kingdom from the Middle East, September 2012. Euro Surveill 17: 1-5.

Blackwood JC, Streicker DG, Altizer S, Rohani P 2013. Resolving the roles of immunity, pathogenesis and immigration for rabies persistence in vampire bats. Proc Natl Acad Sci USA 110: 20837-20842.

Blehert DS, Hicks AC, Behr M, Meteyer CU, Berlowski-Zier BM, Buckles EL, Coleman JT, Darling SR, Gargas A, Niver R, Okoniewski JC, Rudd RJ, Stone WB 2009. Bat white-nose syndrome: an emerging fungal pathogen? Science 323: 227.

Boonman A, Bumrungsri S, Yovel Y 2014. Nonecholocating fruit bats produce biosonar clicks with their wings. Current Biology 24: $2962-2967$

Bouliere F 1958. The comparative biology of aging. J Gerontol 13: $16-24$

Bouma HR, Carey HV, Kroese FG 2010. Hibernation: the immune system at rest? J Leukoc Biol 88: 619-624.

Brook CE, Dobson AP 2015. Bats as 'special' reservoirs for emerging zoonotic pathogens. Trends Microbiol doi: 10.1016/j. tim.2014.12.004.
Butler JE, Wertz N, Zhao Y, Zhang S, Bao Y, Bratsch S, Kunz TH, Whitaker Jr JO, Schountz T 2011. The two suborders of chiropterans have the canonical heavy-chain immunoglobulin (Ig) gene repertoire of eutherian mammals. Dev Comp Immunol 35: 273-284.

Calisher CH 2015. Viruses in bats: a historic review. In L-F Wang, Bats and viruses: from pathogen discovery to host genomics, John Wiley \& Sons, New York.

Calisher CH, Childs JE, Field HE, Holmes KV, Schountz T 2006. Bats: important reservoir hosts of emerging viruses. Clin Microbiol Rev 19: 531-545.

Calisher CH, Ellison JA 2012. The other rabies viruses: the emergence and importance of lyssaviruses from bats and other vertebrates. Travel Med Infect Dis 10: 69-79.

Carini A 1911. Sur une grande epizootic de rage. Ann Inst Pasteur (Paris) 25: 843-846

Ceballos G, Ehrlich PR 2006. Global mammal distributions, biodiversity hotspots and conservation. Proc Natl Acad Sci USA 103: 19374-19379.

Chadha MS, Comer JA, Lowe L, Rota PA, Rollin PE, Bellini WJ, Ksiazek TG, Mishra A 2006. Nipah virus-associated encephalitis outbreak, Siliguri, India. Emerg Infect Dis 12: 235-240.

Chua KB, Bellini WJ, Rota PA, Harcourt BH, Tamin A, Lam SK, Ksiazek TG, Rollin PE, Zaki SR, Shieh W, Goldsmith CS, Gubler DJ, Roehrig JT, Eaton B, Gould AR, Olson J, Field H, Daniels P, Ling AE, Peters CJ, Anderson LJ, Mahy BW 2000. Nipah virus: a recently emergent deadly paramyxovirus. Science 288: 1432-1435.

Chua KB, Koh CL, Hooi PS, Wee KF, Khong JH, Chua BH, Chan YP, Lim ME, Lam SK 2002. Isolation of Nipah virus from Malaysian island flying-foxes. Microbes Infect 4: 145-151.

Daszak P, Zambrana-Torrelio C, Bogich TL, Fernandez M, Epstein JH, Murray KA, Hamilton H 2013. Interdisciplinary approaches to understanding disease emergence: the past, present and future drives of Nipah virus emergence. Proc Natl Acad Sci USA 110: 3681-3688.

Davis A, Gordy P, Rudd R, Jarvis JA, Bowen RA 2012. Naturally acquired rabies virus infections in wild-caught bats. Vector Borne Zoonotic Dis 12: 55-60.

Dobson AP 2006. Response to: linking bats to emerging diseases. Science 311: 1999.

Dobson GE 1875. Conspectus of the suborders, families and genera of Chiroptera arranged according to their natural affinities. The Annals and Magazine of Natural History, series 4 16: 345-357.

Drexler JF, Corman VM, Gloza-Rausch F, Seebens A, Annan A, Ipsen A, Kruppa T, Müller MA, Kalko EK, Adu-Sarkodie Y, Oppong S, Drosten C 2009. Henipavirus RNA in African bats. PLoS ONE 4: e6367.

Drexler JF, Corman VM, Wegner T, Tateno AF, Zerbinati RM, GlozaRausch F, Seebens A, Müller MA, Drosten C 2011. Amplification of emerging viruses in a bat colony. Emerg Infect Dis 17: 449-456.

Eger JL 2008. Genus Cynomops O Thomas, 1920. In AL Gardner, Mammals of South America, Vol. 1, Marsupials, xenarthrans, shrews and bats, University of Chicago Press, Chicago, p. 402-407.

Epstein JH, Baker ML, Zambrana-Torrelio C, Middleton D, Barr JA, Dubovi E, Boyd V, Pope B, Todd S, Crameri G, Walsh A, Pelican K, Fielder MD, Davies AJ, Wang LF, Daszak P 2013. Duration of maternal antibodies against canine distemper virus and Hendra virus in pteropid bats. PLOS ONE 8: e67584.

Fenton MB 1983. Just bats, University of Toronto Press, Toronto, $165 \mathrm{pp}$.

Fenton MB, Davison M, Kunz TH, McCracken GF, Racey PA, Tuttle MD 2006. Linking bats to emerging diseases. Science 311: 1998-1999. 
Fenton MB, Simmons NB 2015. Bats, a world of science and mystery, The University of Chicago Press, Chicago, 303 pp.

Fraser GC, Hooper PT, Lunt RA, Gould AR, Gleeson LJ, Hyatt AD, Russell GM, Kattenbelt JA 1996. Encephalitis caused by a lyssavirus in fruit bats in Australia. Emerg Infect Dis 2: 327-331.

Gire SK, Goba A, Andersen KG, Sealfon RS, Park DJ, Kanneh L, Jalloh S, Momoh M, Fullah M, Dudas G, Wohl S, Moses LM, Yozwiak NL, Winnicki S, Matranga CB, Malboeuf CM, Qu J, Gladden AD, Schaffner SF, Yang X, Jiang PP, Nekoui M, Colubri A, Coomber MR, Fonnie M, Moigboi A, Gbakie M, Kamara FK, Tucker V, Konuwa E, Saffa S, Sellu J, Jalloh AA, Kovoma A, Koninga J, Mustapha I, Kargbo K, Foday M, Yillah M, Kanneh F, Robert W, Massally JL, Chapman SB, Bochicchio J, Murphy C, Nusbaum C, Young S, Birren BW, Grant DS, Scheiffelin JS, Lander ES, Happi C, Gevao SM, Gnirke A, Rambaut A, Garry RF, Khan SH, Sabeti PC 2014. Genomic surveillance elucidates Ebola virus origin and transmission during the 2014 outbreak. Science 345: 1369-1372.

Goldwasser RA, Kissling RE 1958. Fluorescent antibody staining of street and fixed rabies virus antigens. Proc Soc Exp Biol Med 98: 219-223.

Gould EG 1988. Wing-clapping sounds of Eonycteris spelaea (Pteropodidae) in Malaysia. J Mammal 69: 378-379.

Hall L, Richards G 2000. Flying foxes, fruit and blossom bats of Australia, Krieger Publishing Company, Malabar, Florida, viii + 135 pp.

Halpin K, Young PL, Field HE, Mackenzie JL 2000. Isolation of Hendra virus from pteropid bats: a natural reservoir of Hendra virus. J Gen Virol 81: 1927-1932.

Hayman DT, Suu-Ire R, Breed AC, McEachern JA, Wang L, Wood JL, Cunningham AA 2008. Evidence of henipavirus infection in West African fruit bats. PLoS ONE 3: e2739.

Ithete NL, Stoffberg S, Corman VM, Cottontail VM, Richards LR, Schoeman MC, Drosten C, Drexler JF, Preiser W 2013. Close relative of human Middle East respiratory syndrome coronavirus in bat, South Africa. Emerg Infect Dis 19: 1697-1699.

Jahrling PB, Geisbert TW, Dalgard DW, Johnson ED, Ksiazek TG, Hall WC, Peters CJ 1990. Preliminary report: isolation of Ebola virus from monkeys imported to USA. Lancet 335: 502-505.

Johnson KM, Lange JV, Webb PA, Murphy FA 1977. Isolation and partial characterisation of a new virus causing acute haemorrhagic fever in Zaire. Lancet 1: 569-571.

Jones G, Jacobs DS, Kunz TH, Willig MR, Racey PA 2009. Carpe noctem: the importance of bats as bioindicators. Endanger Species Res 8: 93-115.

Koopman KF 1984. A synopsis of the families of bats, part VII. Bat Research News 25: 25-29.

Koopman KF 1994. Chiroptera: systematics. Handbuch der zoologie, Vol. 8, part 60, Mammalia, Walter de Gruyter, Berlin, 217 pp.

Ksiazek TG, Erdman D, Goldsmith CS, Zaki SR, Peret T, Emery S, Tong S, Urbani C, Comer JA, Lim W, Rollin PE, Dowell SF, Ling AE, Humphrey CD, Shieh WJ, Guarner J, Paddock CD, Rota P, Fields B, De Risi J, Yang JY, Cox N, Hughes JM, LeDuc JW, Bellini WJ, Anderson LJ, the SARS Working Group 2003. A novel coronavirus associated with severe acute respiratory syndrome. N Engl J Med 348: 1953-1966.

Kunz TH, Braun de Torrez E, Bauer D, Lobova T, Fleming TH 2011. Ecosystem services provided by bats. Ann NY Acad Sci 1223: 1-38.

Kunz TH, Pierson ED 1994. Bats of the world: an introduction. In R Nowak, Walker's bats of the world, Johns Hopkins University Press, Baltimore, p. 1-46.
Kupferschmidt K 2013. Link to MERS virus underscores bat's puzzling threat. Science 341: 948-949.

Lau SK, Woo PC, Li KS, Huang Y, Tsoi HW, Wong BH, Wong SS, Leung SY, Chan KH, Yuen KY 2005. Severe acute respiratory syndrome coronavirus-like virus in Chinese horseshoe bats. Proc Natl Acad Sci USA 102: 14040-14045.

Le Guenno B, Formenty P, Wyers M, Gounon P, Walker F, Boesch C 1995. Isolation and partial characterization of a new strain of Ebola virus. Lancet 345: 1271-1274.

Leroy EM, Kumulungui B, Pourrut X, Rouquet P, Hassanin A, Yaba P, Délicat A, Paweska JT, Gonzalez JP, Swanepoel R 2005. Fruit bats as reservoirs of Ebola virus. Nature 438: 575-576.

Li WD, Shi ZL, Yu M, Ren WZ, Smith C, Epstein JH, Wang H, Crameri G, Hu Z, Zhang H, Zhang J, McEachern J, Field H, Daszak P, Eaton BT, Zhang S, Wang LF 2005. Bats are natural reservoirs of SARS-like coronaviruses. Science 310: 676-679.

Lima EQ 1934. A transmissão da raiva dos herbívoros pelos morcegos hematófagos da familia Desmondontidae. Rev Dep Nac Prod Anim (Rio de Janeiro) 1: 165-175.

Lobova TA, Geiselman CK, Mori SA 2009. Seed dispersal by bats in the Neotropics, The New York Botanical Garden Press, New York, $471 \mathrm{pp}$.

Luckett WP 1980. The use of fetal membrane data in assessing chiropteran phylogeny. In DE Wilson, AL Gardner (eds.), Proceedings of the Fifth International Bat Research Conference, Texas Tech Press, Lubbock, p. 245-265.

Luis AD, Hayman DT, O'Shea TJ, Cryan PM, Gilbert AT, Pulliam JR, Mills JN, Timonin ME, Willis CK, Cunningham AA, Fooks AR, Rupprecht CE, Wood JL, Webb CT 2013. A comparison of bats and rodents as reservoirs of zoonotic viruses: are bats special? Proc Biol Sci 280: 1-9.

Mandl JN, Ahmed R, Barreiro LB, Daszak P, Epstein JH, Virgin HW, Feinberg MB 2015. Reservoir host immune responses to emerging zoonotic viruses. Cell 160: 20-35.

Marsh GA, de Jong C, Barr JA, Tachedjian M, Smith C, Middleton D, Yu M, Todd S, Foord AJ, Haring V, Payne J, Robinson R, Broz I, Crameri G, Field HE, Wang LF 2012. Cedar virus: a novel henipavirus isolated from Australian bats. PLoS Pathog 8: e1002836.

Marshall LG, Webb SD, Sepkoski JJ, Raup DM 1982. Mammalian evolution and the Great American Interchange. Science 215: 1351-1357.

Melaun C, Werblow A, Busch MW, Klimpel S 2014. Bats as potential reservoir hosts for vector-borne diseases. In S Klimpel, H Mehlhorn, Bats (Chiroptera) as vectors of diseases and parasites, Parasitology Research Monographs 5, Springer-Verlag, Heidelbergh, p. 25-61.

Memish ZA, Mishra N, Olival KJ, Fagbo SF, Kapoor V, Epstein JH, Alhakeemm R, Durosinloun A, Asmari MA, Islam A, Kapoor A, Briese T, Daszak P, Rabeeah AAA, Lipkin WI 2013. Middle East respiratory syndrome coronavirus in bats, Saudi Arabia. Emerg Infect Dis 19: 1819-1823.

Meteyer CU, Barber D, Mandl JN 2012. Pathology in euthermic bats with white nose syndrome suggests a natural manifestation of immune reconstitution inflammatory syndrome. Virulence 3: 583-588.

Mickleburgh SP, Hutson AM, Racey PA, the IUCN/SSC Chiroptera Specialist Group (compilers) 1992. Old World fruit bats: an action plan for their conservation, International Union for Conservation of Nature and Natural Resources, Gland, viii +252 pp.

Mills JN, Childs JE, Ksiazek TG, Peters CJ, Velleca WM 1995. Methods for trapping and sampling small mammals for virologic testing, US Department of Health \& Human Services, Atlanta, 61 pp. 
Mühldorfer K, Speck S, Kurth A, Lesnik R, Freuling C, Müller T, Kramer-Schadt S, Wibbelt G 2011. Diseases and causes of death in European bats: dynamics in disease susceptibility and infection rates. PLoS ONE 6: e29773.

Muscarella R, Fleming TH 2007. The role of frugivorous bats in tropical forest succession. Biol Rev 82: 573-590.

Myers N, Mittermeier RA, Mittermeier CG, Fonseca GAB, Kent J 2000. Biodiversity hotspots for conservation priorities. Nature 403: 853-858.

Negri A 1903. Beitrag zum studium der aetiologie der tollwuth. Z Hyg Infektionskr 43: 507-528.

Nowak R 1994. Walker's bats of the world, Johns Hopkins University Press, Baltimore, $287 \mathrm{pp}$.

O’Leary MA, Bloch JI, Flynn JJ, Gaudin TJ, Giallombardo A, Giannini NP, Goldberg SL, Kraatz BP, Luo Z, Meng J, Ni X, Novacek MJ, Perini FA, Randall Z, Rougier GW, Sargis EJ, Silcox MT, Simmons NB, Spaulding M, Velazco PM, Weksler M, Wible JR, Cirranello AL 2013. The placental mammal ancestor and the post-KPg radiation of placentals. Science 339: 662-667.

O'Shea TJ, Cryan PM, Cunningham AA, Fooks AR, Hayman DTS, Luis AD, Peel AJ, Plowright RK, Wood JLN 2014. Bat flight and zoonotic viruses. Emerg Infect Dis 20: 741-745.

Olival KJ, Hayman DTS 2014. Filoviruses in bats: current knowledge and future directions. Viruses 6: 1759-1788.

Osborne C, Cryan PM, O'Shea TJ, Oko LM, Ndaluka C, Calisher $\mathrm{CH}$, Berglund AD, Klavetter ML, Bowen RA, Holmes KV, Dominguez SR 2011. Alphacoronaviruses in New World bats: prevalence, persistence, phylogeny and potential for interaction with humans. PLOS ONE 6: e19156.

Papenfuss AT, Baker ML, Feng ZP, Tachedjian M, Crameri G, Cowled C, Ng J, Janardhana V, Field HE, Wang LF 2012. The immune gene repertoire of an important viral reservoir, the Australian black flying-fox. BMC Genomics 13: 261.

Parrish CR, Holmes EC, Morens DM, Park E-C, Burke DS, Calisher CH, Laughlin CA, Saif LJ, Daszak P 2008. Cross-species viral transmission and the emergence of new epidemic diseases. $\mathrm{Mi}$ crobiol Mol Biol Rev 72: 457-470.

Pawan JL 1936. The transmission of paralytic rabies in Trinidad by the vampire bat (Desmodus rotundus murinus Wagner, 1840). Ann Trop Med Parasitol 30: 101-129.

Pawan JL 1948. Fruit-eating bats and paralytic rabies in Trinidad. Ann Trop Med Parasitol 42: 173-177.

Pettigrew JD 1995. Flying primates: crashed, or crashed through? In PA Racey, SM Swift, Ecology, evolution and behavior of bats, Zoological Society of London Symposia 67, Oxford University Press, Oxford, p. 3-26.

Plowright RK, Eby P, Hudson PJ, Smith IL, Westcott D, Bryden WL, Middleton D, Reid PA, McFarlane RA, Martin G, Tabor GM, Skerratt LF, Anderson DL, Crameri G, Quammen D, Jordan D, Freeman P, Wang LF, Epstein JH, Marsh GA, Kung NY, McCallum $\mathrm{H}$ 2015. Ecological dynamics of emerging bat virus spillover. Proc Biol Sci 282: 20142124.

Podlutsky AJ, Khritankov AM, Ovodov ND, Austad SN 2005. A new field record for bat longevity. J Gerontol A Biol Sci Med Sci 60: 1366-1368.

Poon LL, Chu DK, Chan KH, Wong OK, Ellis TM, Leung YH, Lau SK, Woo PC, Suen KY, Yuen KY, Guan Y, Peiris JS 2005. Identification of a novel coronavirus in bats. J Virol 79: 2001-2009.

Raj VS, Farag EA, Reusken CB, Lamers MM, Pas SD, Voermans J, Smits SL, Osterhaus AD, Al-Mawlawi N, Al-Romaihi HE, AlHajri MM, El-Sayed AM, Mohran KA, Ghobashy H, Alhajri F,
Al-Thani M, Al-Marri SA, El-Maghraby MM, Koopmans MP, Haagmans BL 2014. Isolation of MERS coronavirus from a dromedary camel, Qatar, 2014. Emerg Infect Dis 20: 1339-1342.

Reynes JM, Counor D, Ong S, Faure C, Seng V, Molia S, Walston J, Georges-Courbot MC, Deubel V, Sarthou JL 2005. Nipah virus in Lyle's flying foxes, Cambodia. Emerg Infect Dis 11: 1042-1047.

Rota PA, Oberste MS, Monroe SS, Nix WA, Campagnoli R, Icenogle JP, Peñaranda S, Bankamp B, Maher K, Chen MH, Tong S, Tamin A, Lowe L, Frace M, DeRisi JL, Chen Q, Wang D, Erdman DD, Peret TC, Burns C, Ksiazek TG, Rollin PE, Sanchez A, Liffick S, Holloway B, Limor J, McCaustland K, Olsen-Rasmussen M, Fouchier R, Günther S, Osterhaus AD, Drosten C, Pallansch MA, Anderson LJ, Bellini WJ 2003. Characterization of a novel coronavirus associated with severe acute respiratory syndrome. Science 300: 1394-1399.

Ryan PA, Martin L, Mackenzie JS, Kay BH 1997. Investigation of gray-headed flying foxes (Pteropus poliocephalus) (Megachiroptera: Pteropodidae) and mosquitoes in the ecology of Ross River virus in Australia. Am J Trop Med Hyg 57: 476-482.

Rydell J, Speakman JR 1995. Evolution of nocturnality in bats: potential competitors and predators during their early history. Biol $J$ Linn Soc Lond 54: 183-191.

Saéz AM, Weiss S, Nowak K, Lapeyre V, Zimmermann F, Düx A, Kühl HS, Kaba M, Regnaut S, Merkel K, Sachse A, Thiesen U, Villányi L, Boesch C, Dabrowski PW, Radonić A, Nitsche A, Leendertz SAJ, Petterson S, Becker S, Krähling V, Couacy-Hymann E, Akoua-Koffi C, Weber N, Schaade L, Fahr J, Borchert M, Gogarten JF, Calvignac-Spencer S, Leendertz FH 2015. Investigating the zoonotic origin of the West African Ebola epidemic. EMBO Mol Med 7: 17-23.

Sazima I, Vogel S, Sazima M 1989. Bat pollitation of Encholirium glaziovii, a terrestrial bromeliad. Plant Syst Evol 168: 167-179.

Sazima M, Buzato S, Sazima I 2003. Dyssochroma viridiflorum (Solanaceae), a reproductively bat-dependent, epiphyte from the Atlantic rainforest in Brazil. Annals of Botany 92: 725-730.

Seim I, Fang X, Xiong Z, Lobanov AV, Huang Z, Ma S, Feng Y, Turanov AA, Zhu Y, Lenz TL, Gerashchenko MV, Fan D, Yim SH, Yao X, Jordan D, Xiong Y, Ma Y, Lyapunov AN, Chen G, Kulakova OI, SunY, Lee S-G, Bronson RT, Moskalev AA, Sunyaev SR, Zhang G, Krogh A, Wang J, Gladyshev VN 2013. Genome analysis reveals insights into physiology and longevity of the Brandt's bat Myotis brandtii. Nat Commun 4: 1-8.

Selvey LA, Wells RM, McCormack JG, Ansford AJ, Murray K, Rogers RJ, Lavercombe PS, Selleck P, Sheridan JW 1995. Infection of humans and horses by a newly described morbillivirus. Med $J$ Aust 162: 642-645.

Seymour C, Dickerman RW, Martin MS 1978a. Venezuelan encephalitis virus infection in neotropical bats. I. Natural infection in a Guatemalan enzootic focus. Am J Trop Med Hyg 27: 290-296.

Seymour C, Dickerman RW, Martin MS 1978b. Venezuelan encephalitis virus infection in neotropical bats. II. Experimental infections. Am J Trop Med Hyg 27: 297-306.

Shaw TI, Srivastava A, Chou WC, Liu L, Hawkinson A, Glenn TC, Adams R, Schountz T 2012. Transcriptome sequencing and annotation for the Jamaican fruit bat (Artibeus jamaicensis). PLoS ONE 7: e48472.

Simmons NB 1993. The importance of methods: Archontan phylogeny and cladistics analysis of morphological data. In RDE MacPhee, Primates and their relatives in phylogenetic perspective. Advances in Primatology Series, Plenum Publishing, New York, pp. 1-61.

Simmons NB 1994. The case for chiropteran monophyly. Am Mus Novit 3103: 1-54. 
Simmons NB 1995. Bat relationships and the origin of flight. In PA Racey, SM Swift, Ecology, evolution and behavior of bats, Zoological Society of London Symposia 67, Oxford University Press, Oxford, p. 27-43.

Simmons NB 1998. A reappraisal of interfamilial relationships of bats. In TH Kunz, PA Racey, Bat biology and conservation, Smithsonian Institution Press, Washington DC, p. 3-26.

Simmons NB 2005. Order Chiroptera. In DE Wilson, DM Reeder, Mammal species of the world: a taxonomic and geographic reference, 3rd ed., Vol. 1, Johns Hopkins University Press, Baltimore, p. 312-529.

Simmons NB, Geisler JH 1998. Phylogenetic relationships of Icaronycteris, Archaeonycteris, Hassianycteris and Palaeochiropteryx to extant bat lineages with comments on the evolution of echolocation and foraging strategies in Microchiroptera. B Am Mus Nat Hist 235: 1-182.

Simmons NB, Novacek MJ, Baker RJ 1991. Approaches, methods and the future of the chiropteran monophyly controversy: a reply to J. D. Pettigrew. Syst Zool 40: 239-243.

Simmons NB, Seymour KL, Habersetzer J, Gunnell GF 2008. Primitive Early Eocene bat from Wyoming and the evolution of flight and echolocation. Nature 451: 818-821.

Simmons NB, Voss R 1998. The mammals of Paracou, French Guiana: a Neotropical lowland rainforest fauna, part 1, bats. $B A m M u s$ Nat Hist 237: 1-219.

Simon R, Holderied MW, Koch CU, von Helversen O 2011. Floral acoustics: conspicuous echoes of a dish-shaped leaf attract bat pollinators. Science 333: 631-633.

Siu KL, Yeung ML, Kok KH, Yuen KS, Kew C, Lui PY, Chan CP, Tse H, Woo PC, Yuen KY, Jin DY 2014. Middle East respiratory syndrome coronavirus 4a protein is a double-stranded RNA-binding protein that suppresses PACT-induced activation of RIG-I and MDA5 in the innate antiviral response. $J$ Virol 88: 4866-4876.

Springer MS, Teeling EC, Madsen O, Stanhope MJ, Jong WW 2001. Integrating fossil and molecular data reconstruct bat echolocation. Proc Natl Acad Sci USA 98: 6241-6246.

Steece R, Calisher CH 1989. Isolation of rabies virus from fetal tissues of Tadarida brasiliensis. J Wildl Dis 25: 329-334.

Sulkin SE, Allen R, Sims R, Singh KV 1966. Studies of arthropodborne virus infections in Chiroptera. IV. Immune response of big brown bat (Eptesicus f. fuscus) maintained at various environmental temperatures to experimental Japanese B encephalitis virus infection. Am J Trop Med Hyg 15: 418-427.

Swanepoel R, Leman PA, Burt FJ, Zachariades NA, Braack LE, Ksiazek TG, Rollin PE, Zaki SR, Peters CJ 1996. Experimental inoculation of plants and animals with Ebola virus. Emerg Infect Dis 2: 321-325.

Swanepoel R, Smit SB, Rollin PE, Formenty P, Leman PA, Kemp A, Burt FJ, Grobbelaar AA, Croft J, Bausch DG, Zeller H, Leirs H, Braack LEO, Libande ML, Zaki S, Nichol ST, Ksiazek TG, Paweska JT 2007. Studies of reservoir hosts for Marburg virus. Emerg Infect Dis 13: 1847-1851.

Teeling EC, Dool S, Springer MS 2012. Phylogenies, fossils and functional genes: the evolution of echolocation in bats. In GF Gunnell, NB Simmons, Evolutionary history of bats: fossils, molecules and morphology, Cambridge University Press, Cambridge, p. 1-22.

Towner JS, Amman BR, Sealy TK, Carroll SA, Comer JA, Kemp A, Swanepoel R, Paddock CD, Balinandi S, Khristova ML, Formenty
PB, Albarino CG, Miller DM, Reed ZD, Kayiwa JT, Mills JN, Cannon DL, Greer PW, Byaruhanga E, Farnon EC, Atimnedi P, Okware S, Katongole-Mbidde E, Downing R, Tappero JW, Zaki SR, Ksiazek TG, Nichol ST, Rollin PE 2009. Isolation of genetically diverse Marburg viruses from Egyptian fruit bats. PLoS Pathog 5: e1000536.

Towner JS, Sealy TK, Khristova ML, Albariño CG, Conlan S, Reeder SA, Quan P-L, Lipkin WI, Downing R, Tappero JW, Okware SW, Lutwama J, Bakamutumaho B, Kayiwa J, Comer JA, Rollin PE, Ksiazek TG, Nichol ST 2008. Newly discovered Ebola virus associated with hemorrhagic fever outbreak in Uganda. PLoS Pathog 4: e1000212.

Van Den Bussche RA, Hoofer SR 2004. Phylogenetic relationships among recent chiropteran families and the importance of choosing appropriate out-group taxa. J Mammal 85: 321-330.

Voig CC, Zubaid A, Kunz TH, Kingston T 2011. Sources of assimilated proteins in Old and New World phytophagous bats. Biotropica 43: 108-113.

Voss R, Lunde DP, Simmons NB 2001. The mammals of Paracou, French Guiana, a Neotropical lowland rainforest fauna, part 2, nonvolant species. B Am Mus Nat Hist 263: 1-236.

Wacharapluesadee S, Lumlertdacha B, Boongird K, Wanghongsa S, Chanhome L, Rollin P, Stockton P, Rupprecht CE, Ksiazek TG, Hemachudha T 2005. Bat Nipah virus, Thailand. Emerg Infect Dis 11: 1949-1951.

Wibbelt G, Moore MS, Schountz T, Voigt CC 2010. Emerging diseases in Chiroptera: why bats? Biol Lett 6: 438-440.

Wible JR, Novacek MJ 1988. Cranial evidence for the monophyletic origin of bats. Am Mus Novit 2911: 1-19.

Wilkinson GS, South JM 2002. Life history, ecology and longevity in bats. Aging Cell 1: 124-131.

Wilson DE 1973. Bat faunas: a trophic comparison. Syst Zool 22: 14-29.

Wilson DE 1997. Bats in question: the Smithsonian answer book, Smithsonian Institution Press, Washington DC, 168 pp.

Wilson DE, Reeder DM 2005. Mammal species of the world: a taxonomic and geographic reference, 3rd ed., Vol. 1, Johns Hopkins University Press, Baltimore, $2142 \mathrm{pp}$.

Witte EJ 1954. Bat rabies in Pennsylvania. Am J Public Health Nations Health 44: 186-187.

Wynne JW, Wang L-F 2013. Bats and viruses: friend or foe? PLoS Pathog 9: e1003651.

Zhang G, Cowled C, Shi Z, Huang Z, Bishop-Lilly KA, Fang X, Wynne JW, Xiong Z, Baker ML, Zhao W, Tachedjian M, Zhu Y, Zhou P, Jiang X, Ng J, Yang L, Wu L, Xiao J, Feng Y, Chen Y, Sun X, Zhang Y, Marsh GA, Crameri G, Broder CC, Frey KG, Wang LF, Wang J 2013. Comparative analysis of bat genomes provides insight into the evolution of flight and immunity. Science 339: 456-460.

Zhang H, Todd S, Tachedjian M, Barr JA, Luo M, Yu M, Marsh GA, Crameri G, Wang L-F 2012. A novel bat herpesvirus encodes homologues of major histocompatibility complex classes I and II, C-type lectin and a unique family of immune-related genes. $J$ Virol 86: 8014-8030.

Zhou P, Cowled C, Mansell A, Monaghan P, Green D, Wu L, Shi Z, Wang LF, Baker ML 2014. IRF7 in the Australian black flyingfox, Pteropus alecto: evidence for a unique expression pattern and functional conservation. PLoS ONE 9: e103875. 